\title{
Can ecosystem properties be fully translated into service values? An economic valuation of aquatic plant services
}

\author{
Marina García-Llorente, ${ }^{1,3}$ Berta Martín-López, ${ }^{1}$ Sandra Díaz, ${ }^{2}$ and Carlos Montes ${ }^{1}$ \\ ${ }^{1}$ Social-Ecological Systems Laboratory, Department of Ecology, c. Darwin, 2, Edificio de Biología, \\ ${ }^{2}$ Instituto Multidisciplinario de Biología Vegetal (CONICET-UNC) y Facultad de Ciencias Exactas, Físicas y Naturales, \\ Universidad Nacional de Córdoba, Casilla de Correo 495, 5000 Córdoba, Argentina
}

\begin{abstract}
We carried out an integrated analysis of ecosystem services in the Donana social-ecological system (southwestern Spain), from the providers (different aquatic plant functional groups) to the beneficiaries (different stakeholders living in or visiting the area). We explored the ecosystem services supplied by aquatic plants by linking these services to different plant functional traits, identifying relevant ecosystem services and then working our way backward to ecosystem properties and the functional traits underpinning them. We started from 15 ecosystem services associated with aquatic systems (freshwater marshes, salt marshes, ponds on aeolian sheets, temporal coastal ponds, and estuaries) and related them to plant traits (directly or indirectly through intermediate ecosystem properties). We gathered information from the literature on the functional traits of 144 plants occurring in the aquatic ecosystems of Doñana. We analyzed the species $\times$ trait matrix with multivariate classification and ordination techniques and obtained seven functional groups with different potentials for delivering ecosystem services. A survey was then administered to 477 stakeholders to analyze, through the use of a contingent valuation exercise, how the ecosystem services provided by the different functional groups were valued. We identified connections between individual plant traits, ecosystem processes, and ecosystem services, but a mismatch appeared between the functional groups and the economic values placed on them by the beneficiaries. We found that contingent valuation applied to ecosystem services tended to ignore the ecosystem properties and biodiversity underpinning them. Our results cast doubts over the suitability of the economic valuation framework of ecosystem services to capture the full value of biodiversity and ecosystems to people.
\end{abstract}

Key words: aquatic vegetation; beneficiaries; contingent valuation; Doñana social-ecological system; ecosystem services; functional diversity; providers.

\section{INTRODUCTION}

Social systems and ecosystems are strongly interlinked, forming social-ecological systems (SES; Folke et al. 2003, Turner et al. 2003, Ostrom 2009). With its long and intense history of human occupation (Blondel 2006) and the present strong pressures from urbanization, tourism, and agriculture (Underwood et al. 2008), the Mediterranean basin is a particularly compelling example of a SES. These human-induced pressures are altering all components of biodiversity and ecosystems in the region (Gómez-Baggethun et al. 2010), including their functional trait composition. Functional traits (i.e., the physiological, structural, behavioral, or phenological characteristics of the organisms that form an ecosystem) have been shown to play important roles in the provision of many ecosystem services, especially in the case of plants (Chapin et al. 2000, Hooper et al. 2005, Díaz et al. 2006, 2011).

Manuscript received 10 September 2010; revised 10 June 2011; accepted 21 June 2011; final version received 12 July 2011. Corresponding Editor: E. H. Stanley.

${ }^{3}$ E-mail: marina.garcia@uam.es
Here, we define functional trait composition (functional trait diversity) as the value, range, distribution, and relative abundance of functional traits of organisms (Díaz and Cabido 2001, Díaz et al. 2007, 2011). The identification of the specific component of biodiversity providing a given ecosystem service (hereafter, ecosystem service provider, or ESP) is an important starting point in ecosystem service assessment (Luck et al. 2009, Harrington et al. 2010). Functional groups (i.e., groups of species that show similarities in their functional trait values) are often a useful way to define ESPs because they can be constructed on the basis of those functional traits that are important to a given ecosystem property or service of interest (Luck et al. 2009). Additionally, research into ecosystem services requires the identification of the beneficiaries of these services (ESBs) and the way in which these beneficiaries perceive and value the service (Egoh et al. 2007). However, a recent review has concluded that most studies of ecosystem services do not explicitly include the preferences and values of different ESBs (Menzel and Teng 2010). Separating ecosystem services from their perceived value, as is currently 


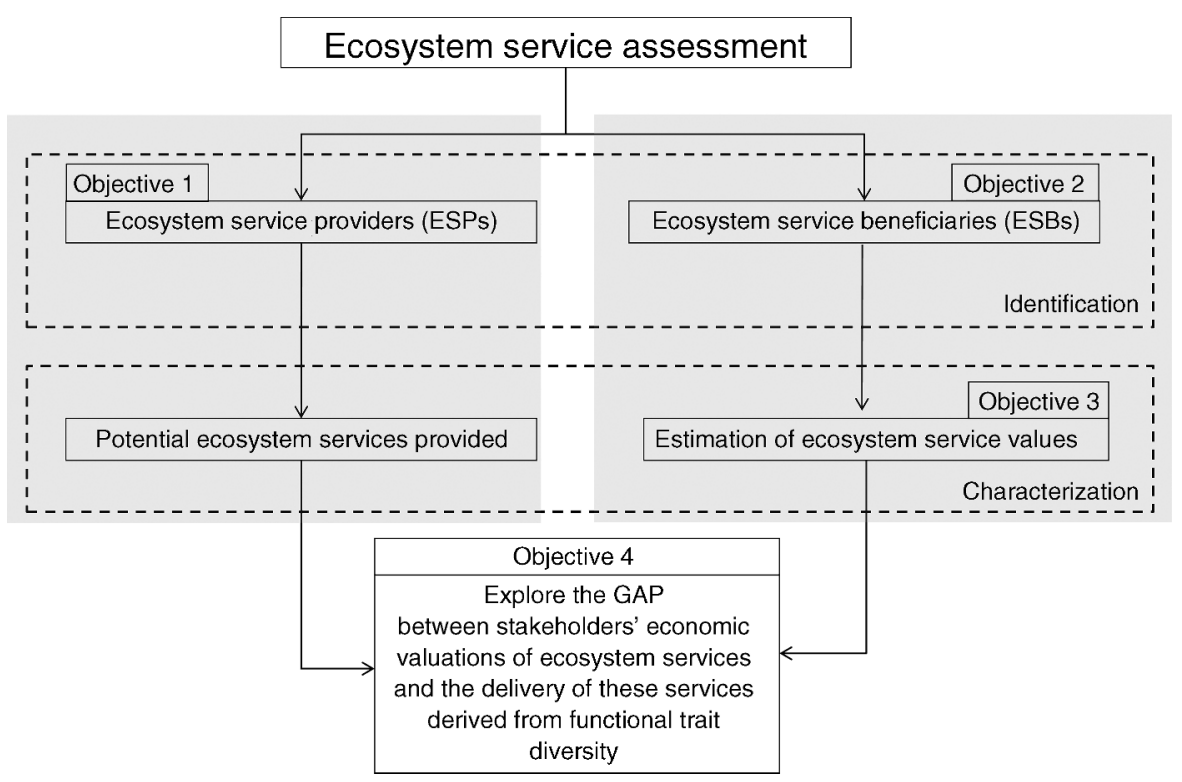

FIG. 1. Conceptual framework showing the links between ecosystem service providers (ESPs) and ecosystem service beneficiaries (ESBs) and how we explored these links. Gray-shaded boxes on the left and right sides refer to the ecological and socioeconomic dimensions studied here. Boxes outlined by heavy dashed lines on the top and bottom refer to the identification and characterization stages.

practiced, suggests that these services can be defined without reference to the values of those who benefit from them. In contrast, different ESBs usually have different priorities regarding which ecosystem services are most important to their well-being (McMichael et al. 2005, Díaz et al. 2011).

In ecosystem service assessments, ecologists study the system and organismal characteristics required to deliver services, whereas economists tend to explore different approximations for determining the economic value of services. An explicit quantification of the links between the characteristics of the ESP and service provision is lacking in ecosystem service economic valuation approaches (Kontogianni et al. 2010). An interdisciplinary research that explores the linkages between components of functional diversity and ecosystem service delivery is therefore in order (Carpenter et al. 2009, Anton et al. 2010, Díaz et al. 2011). In this study, we integrated methodologies from ecology, sociology, and environmental economics with the aim of identifying and characterizing the ESPs, ESBs, and the way in which ESBs value ecosystem services in one of the most important wetlands of Mediterranean Europe, Doñana. The main objective of this investigation was to explore the existing gap between the supply of ecosystem services by functional diversity and the final ecosystem services valued by stakeholders (Fig. 1). Specifically, we (1) identified ESPs through the characterization of functional groups of aquatic vegetation that contribute to services delivery, (2) identified and characterized ESBs, (3) estimated the economic value of the ecosystem services provided by functional groups, and (4) explored the gap between stakeholders' economic valuations of ecosystem services and the delivery of these services derived from functional diversity.

This integrated analysis of ecosystem services from the providers to the beneficiaries was tested in the Doñana SES. The results of this empirical study should provide information on how ESBs value ecosystem services and how well they understand the role of functional diversity in the provision of these services. We argue that this information is useful for exploring the risk associated with considering the biophysical or the socioeconomic dimensions of ecosystem services in an isolated way in conservation and environmental policies.

\section{STudy Area}

The study was conducted in the Doñana SES, which extends along the coastal plain of the Gulf of Cadiz from the left bank of the estuary of the Guadalquivir River to the estuary of the Tinto River in the southwest of Spain (Fig. 2). The Doñana SES is considered the most important wetland area in Spain (Serrano et al. 2006). For this reason, approximately 110000 ha are under different levels of environmental protection: as a national park of 54252 ha (designated as a Ramsar site in 1982 and a World Heritage Site by UNESCO in 1995) and as a natural park of 53835 ha (created as a surrounding protection area in 1989).

The ecosystems of Doñana are marshes, aeolian sheets, coastal systems, and an estuary, which are collectively referred to as the Greater Fluvial-Littoral Ecosystem of Doñana (220 070 ha; Montes et al. 1998). 


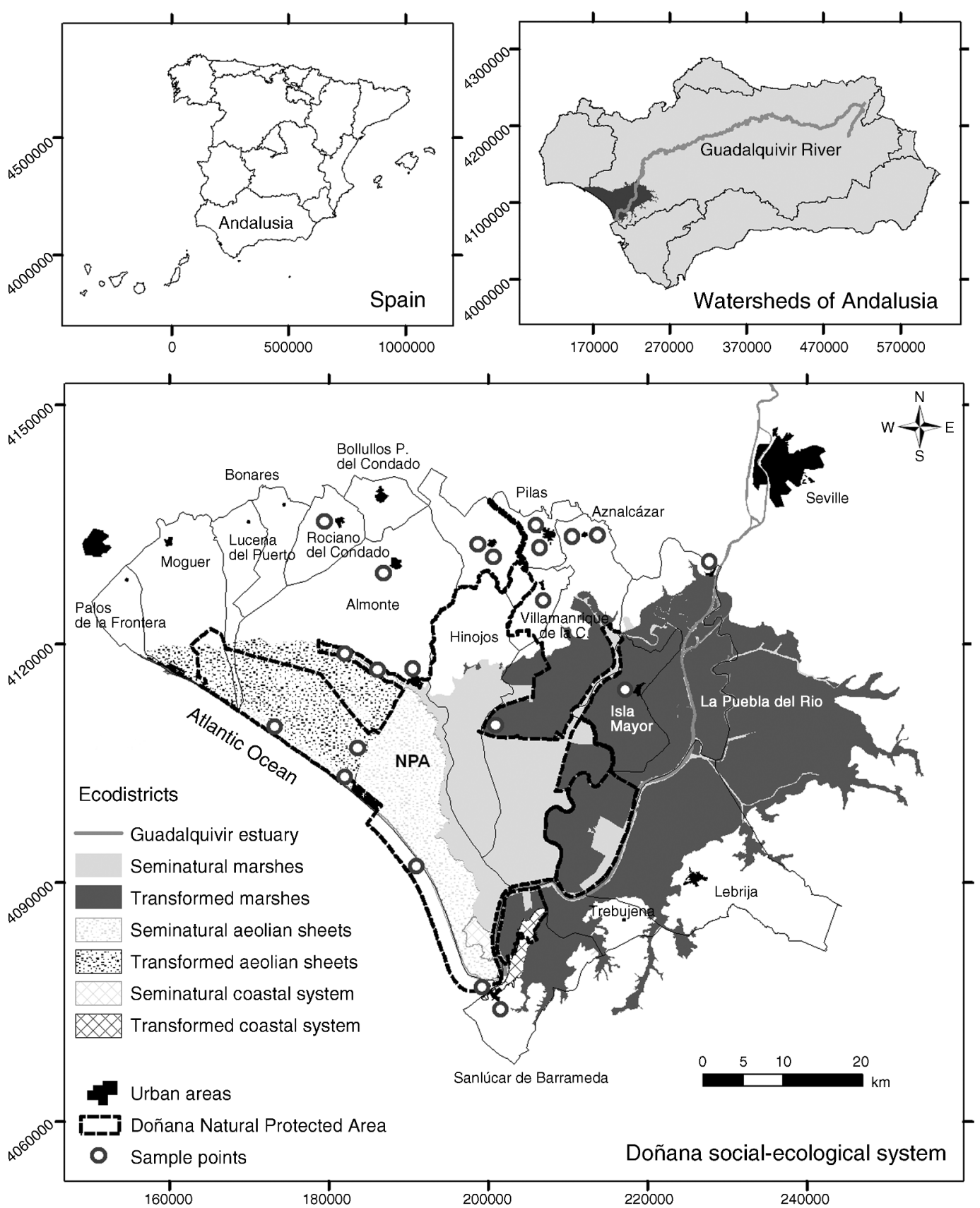

FIG. 2. Study area and sample points. Coordinates are UTM.

We restricted the present study to the aquatic systems: freshwater marshes, salt marshes, ponds on the aeolian sheets, temporal coastal ponds, and the estuary.

Wetlands are well known for their important roles in providing provisioning (e.g., agricultural and fish production, water supply), regulating (e.g., sediment trapping and water purification), and cultural services (e.g., aesthetic values, ecotourism, and spiritual values) (Mitsch et al. 1995, Wilson and Carpenter 1999, Harrison et al. 2010). The composition of aquatic plant communities may affect wetland ecosystem processes and the provision of the associated ecosystem services (Engelhardt and Ritchie 2002, Espinar et al. 2002). For example, hydrophytes are involved in a number of biochemical processes in the water column (Carpenter and Lodge 1986) and are responsible for much of the productivity and nutrient retention in aquatic environments (Engelhardt and Ritchie 2002). In the Doñana SES, aquatic plants are the main primary producers and play other important ecological roles in providing 


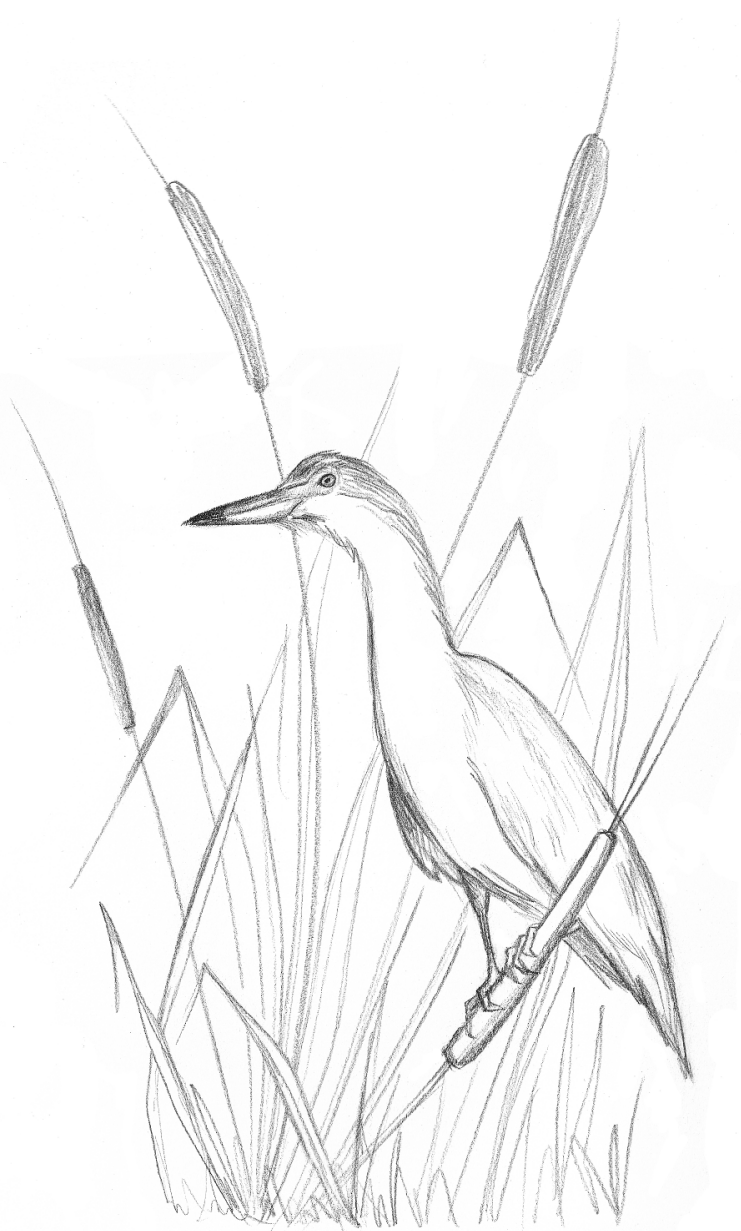

Plate 1. The canopy structure and tall stature of emergent swamp plants such as rushes and sedges provide habitat for waterfowl. Illustration credit: Elena Peña-Riquelme.

ecosystem structure as well as recycling nutrients and other chemical elements (García-Murillo et al. 2006).

From the social point of view, the area is organized into 16 municipalities, with a population of c. 213839 inhabitants, mostly devoted to agriculture and tourism. The history of Doñana SES reflects a continuous process of land use transformation (Ojeda 1992), with agriculture having been the subsistence base of the region until around 1940 (Gómez-Baggethun et al. 2010). Currently, although the Doñana protected area serves a critical role in biodiversity conservation, it is embedded in a matrix of intensive land uses, with increasing conflict between biodiversity conservation and the expansion of agriculture, tourism, and urbanization outside the protected area borders (García-Novo and Marín-Cabrera 2006, Martín-López et al. 2011).

\section{Materials And Methods}

Data sources

Ecological data: bibliographic review of functional traits and ecosystem services provided.-Changes in functional trait diversity can potentially affect ecosystem service delivery directly or indirectly through its effects on ecosystem properties (Díaz et al. 2007, 2011, De Bello et al. 2010). Following Díaz et al. (2007, 2011), we first identified relevant ecosystem services and then worked our way backward to ecosystem properties and the aquatic plant functional traits underpinning them. On the basis of the literature, we first identified ecosystem services generally associated with aquatic systems and related them to plant traits (directly or indirectly) through intermediate ecosystem properties (Table 1). We then conducted a literature review of all the studies of aquatic habitats in the area, identifying which species were present. We found 165 species; we selected those 144 species (belonging to 35 families) for which we were able to obtain complete functional trait information (Appendix A). We then compiled information on 16 functional traits for all species using local, national, and Europe-wide sources (Table 2). Finally, we assessed those ecosystem services that depended on specific species.

Social data: survey design and sampling strategy.Once we characterized the functional groups of aquatic plants that serve as ESPs, we administered a survey to explore ESBs' preferences for the services associated with such ESPs. Questionnaires consisted of the five following sections: (1) the respondent's relationship with the study area, (2) the respondent's perception of the importance of ecosystem services, (3) an economic valuation exercise to identify the respondent's preferences in relation to each ecosystem service provided by the aquatic plant functional groups (previously identified), (4) the respondent's general environmental behavior, and (5) sociodemographic information.

The survey was conducted from July 2008 to March 2009 using questionnaires applied in direct face-to-face interviews. With the aim of gaining as wide a range of social views on ecosystem services delivery as possible, the questionnaires were administered at 20 sampling points in Doñana, including offices, urban zones, visitor centers, beaches, recreational areas, and agricultural fields (Fig. 2). The population sampled was randomly selected to cover a wide range of backgrounds, including both resident and tourist populations. Only individuals 18 years of age or older were interviewed, and the total sample consisted of 477 respondents.

The first section of the questionnaire was designed to motivate respondents to think about the study area. At the beginning of the second section, and to ensure a homogeneous level of knowledge, respondents were informed about the ecosystem services concept. We then asked their opinions on whether Doñana provided any ecosystem services. If the answer was positive, we asked respondents to name examples of services known to them (open question). After that, we presented them with a list of ecosystem services and asked them to name the most important ones. In the third section, each ESP was described in terms of its functional traits and the 
TABLE 1. Connections between individual plant traits, ecosystem properties, and ecosystem services.

\begin{tabular}{|c|c|c|c|}
\hline Ecosystem services & Ecosystem properties & Plant functional traits & References \\
\hline \multicolumn{4}{|l|}{ Provisioning } \\
\hline \multirow[t]{4}{*}{ Fodder for livestock } & \multirow{4}{*}{$\begin{array}{l}\text { biomass production in } \\
\text { adequate quantity and } \\
\text { quality to support } \\
\text { livestock }\end{array}$} & plant height & Díaz et al. (2007) \\
\hline & & body flexibility & $\begin{array}{l}\text { Dawson and Robinson (1984), } \\
\text { Lacoul and Freedman (2006), } \\
\text { Read and Stokes (2006) }\end{array}$ \\
\hline & & leaf texture & $\begin{array}{l}\text { Duarte et al. (1990), Cornelissen et al. } \\
(2003)\end{array}$ \\
\hline & & physical defenses & Levine (2000) \\
\hline \multicolumn{4}{|l|}{ Regulating } \\
\hline \multirow[t]{4}{*}{ Water purification } & \multirow[t]{4}{*}{$\begin{array}{l}\text { water oxygenation, } \\
\text { nutrient retention }\end{array}$} & growth form: submerged & $\begin{array}{l}\text { Mitsch et al. (1995), Wu and Mitsch } \\
\text { (1998) }\end{array}$ \\
\hline & & leaf area & Engelhardt and Ritchie (2002) \\
\hline & & leaf texture & Gusewell (2005) \\
\hline & & root type & $\begin{array}{l}\text { Allen (1997), Engelhardt and } \\
\text { Ritchie (2002), Gusewell (2005), } \\
\text { Macek (2008) }\end{array}$ \\
\hline \multirow[t]{4}{*}{ Water regulation } & \multirow[t]{2}{*}{ runoff retention } & growth form: floating & De Bello et al. (2010) \\
\hline & & body flexibility & $\begin{array}{l}\text { Dawson and Robinson (1984), } \\
\text { Lacoul and Freedman (2006), } \\
\text { Read and Stokes (2006) }\end{array}$ \\
\hline & \multirow{2}{*}{ evapotranspiration } & leaf area & De Bello et al. (2010) \\
\hline & & root type & Macek (2008) \\
\hline \multirow{4}{*}{$\begin{array}{l}\text { Soil formation } \\
\text { and fertility }\end{array}$} & \multirow{3}{*}{$\begin{array}{l}\text { decomposition, nutrient } \\
\text { availability }\end{array}$} & growth form: helophytes & Espinar et al. (2002) \\
\hline & & leaf texture & Espinar et al. (2002) \\
\hline & & root type & $\begin{array}{l}\text { Farmer and Spence (1986), Jaynes } \\
\text { and Carpenter (1986) }\end{array}$ \\
\hline & $\begin{array}{l}\text { soil retention by root } \\
\text { systems }\end{array}$ & root type & Jaynes and Carpenter (1986) \\
\hline \multirow[t]{3}{*}{$\begin{array}{l}\text { Food for important } \\
\text { wild animals }\end{array}$} & \multirow{3}{*}{$\begin{array}{l}\text { shoot, fruit, and seed } \\
\text { production in adequate } \\
\text { quantity and quality to } \\
\text { support waterfowl }\end{array}$} & leaf texture & $\begin{array}{l}\text { Idestram-Almquist (1998), Nolet et } \\
\text { al. (2001), Engelhardt and Ritchie } \\
\text { (2002) }\end{array}$ \\
\hline & & dispersule size & $\begin{array}{l}\text { Idestram-Almquist } \\
\text { (1998), Nolet et al. (2001) }\end{array}$ \\
\hline & & dispersule shape & Charalambidou et al. (2003) \\
\hline $\begin{array}{l}\text { Habitat for important } \\
\text { wild animals }\end{array}$ & canopy structure & $\begin{array}{l}\text { vertical shoot architecture: } \\
\text { multiple apical } \\
\text { meristems }\end{array}$ & $\begin{array}{l}\text { Voigts (1976), Paracuellos } \\
\text { and Tellería (2004), Paracuellos } \\
\text { (2006) }\end{array}$ \\
\hline $\begin{array}{l}\text { Temporal continuity of } \\
\text { primary production in } \\
\text { the face of drought } \dagger\end{array}$ & $\begin{array}{l}\text { peak primary productivity } \\
\text { early in the season }\end{array}$ & early phenology & Chiarello (1989) \\
\hline \multirow{2}{*}{$\begin{array}{l}\text { Temporal continuity of } \\
\text { primary production } \\
\text { in the face of } \\
\text { aboveground disturbance } \uparrow\end{array}$} & \multirow[t]{2}{*}{$\begin{array}{l}\text { persistence in the soil } \\
\text { seed bank }\end{array}$} & seed size & $\begin{array}{l}\text { Thompson et al. (1993), Leishman } \\
\text { and Westoby (1994), Willby et al. } \\
\text { (2000) }\end{array}$ \\
\hline & & seed shape & $\begin{array}{l}\text { Thompson et al. (1993), Bekker et al. } \\
\text { (1998), Willby et al. (2000) }\end{array}$ \\
\hline \multirow{2}{*}{$\begin{array}{l}\text { Tolerance to biotic } \\
\text { disturbance (e.g., } \\
\text { herbivores) } \dagger\end{array}$} & \multirow[t]{2}{*}{ tolerance to trampling } & \multirow{2}{*}{$\begin{array}{l}\text { vegetative reproduction } \\
\text { body flexibility }\end{array}$} & Grace (1993) \\
\hline & & & $\begin{array}{l}\text { Dawson and Robinson (1984), } \\
\text { Lacoul and Freedman (2006), } \\
\text { Read and Stokes (2006) }\end{array}$ \\
\hline $\begin{array}{l}\text { Availability across the } \\
\text { landscape and in situ } \\
\text { perpetuation of important } \\
\text { plants } \dagger\end{array}$ & $\begin{array}{l}\text { seed transport by wind, } \\
\text { water or animals }\end{array}$ & dispersal mode & $\begin{array}{l}\text { Figuerola et al. (2002), Jansson et al. } \\
\text { (2005), Pollux et al. (2005) }\end{array}$ \\
\hline $\begin{array}{l}\text { Landscape flammability } \\
\text { (usually but not always } \\
\text { a disservice) } \dagger\end{array}$ & $\begin{array}{l}\text { standing dead biomass } \\
\text { accumulation }\end{array}$ & leaf lifespan & $\begin{array}{l}\text { Grigulis et al. (2005), Lloret and Vila } \\
\text { (2009) }\end{array}$ \\
\hline \multicolumn{4}{|l|}{ Cultural } \\
\hline $\begin{array}{l}\text { Recreational-aesthetic } \\
\text { services }\end{array}$ & & flower visually attractive & Kendal et al. (2008) \\
\hline
\end{tabular}

Notes: The putative mechanisms have been empirically tested in some cases but have not been evaluated in others. Additionally, we assessed ecosystem services that depend on specific species: medicinal value (Lemna minor; Thomson 1994), direct source of food (Lythrum salicaria and Glyceria fluitans; Rivera-Nuñez and Obón de Castro 1991) and source of fiber for basketwork (Juncus spp.; Rivera-Nuñez and Obón de Castro 1991, Garrido 2000).

$\dagger$ Because of the difficulties in introducing this terminology in the questionnaires conducted, all of these services were conceptualized under the same category, as the capacity of the system to return to a previous state following an event of stress or disturbance (i.e., resilience; Holling 1973). 
TABLE 2. List of the functional traits of aquatic plants compiled for all species using local, national, and Europe-wide sources.

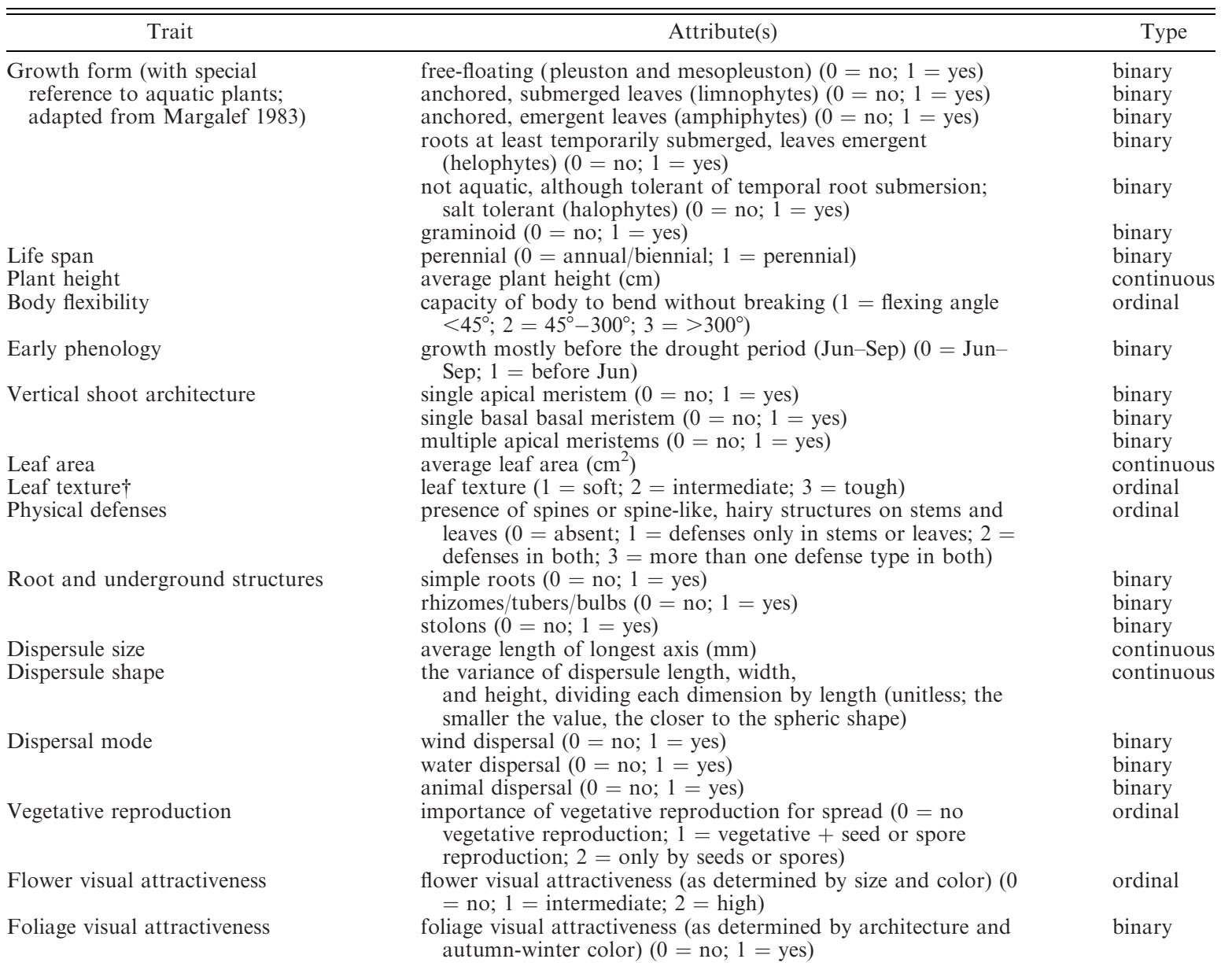

Sources: Figuerola and Green (2002), Figuerola et al. (2005), Valdés et al. (1987), Peco et al. (2003), Iberian Flora Database 〈http://www.floraiberica.es〉, Willby et al. (2000), and Kleyer et al. (2008).

$\dagger$ Because leaf texture is strongly determined by $\mathrm{C}: \mathrm{N}$ ratio, it is used as a proxy for nutrient content, growth rate, decomposition rate, and palatability for herbivores; the tougher the leaf, the stronger all these properties are expected to be, with the exception of growth rate, which is expected to decrease with leaf toughness (on the bases of Coley [1980], Grime et al. [1996], Cornelissen et al. [1999], and Díaz et al. [2004]).

services associated with it, backed up with visual information. Respondents were asked to allocate a hypothetical amount of money for the ecosystem services provided by the ESPs. The fourth section inquired into the respondents' interests in nature, and the fifth focused on their socioeconomic characteristics. Finally, the interviewer answered two follow-up questions to summarize each respondent's attitude and understanding of the interview and its directives. The entire questionnaire is presented in Appendix B.

\section{Data analysis}

Classification of ESPs and ESBs.-Multivariate analyses were performed to explore the underlying factors explaining characteristics of both ESPs (aquatic plant functional groups) and ESBs (stakeholders). Toward this end, we organized the aquatic plant data into a single 16 trait $\times 144$ species matrix, and the social data into a single 18 variable $\times 477$ respondent matrix. Then, a principal component analysis (PCA) was conducted, based on the correlation matrix of variables, in which data are centered and standardized by standard deviation; this analytical method is considered appropriate for mixed data (Jongman et al. 1987). The significant number of factors in the PCA was determined by following the Kaiser criterion (eigenvalue $>1$ ). A hierarchical cluster analysis, through Euclidean distance (percentage of distance similarity at a $95 \%$ of confidence) and Ward's agglomerative method (Ward 1963), was used to identify ESPs (plant functional groups) on the basis of their functional traits, and to characterize ESBs (groups of stakeholders) on the basis of their relationships with the Doñana SES, their perceptions of importance of ecosystem services, and sociodemographic information. This approximation has been also used in other ecological studies, such as Díaz et al. (1992) and 
TABLE 3. Summary of variables used in the social analyses performed, the variables' main attributes, and the analysis in which they were used (principal component analysis [PCA] or Heckman model).

\begin{tabular}{|c|c|c|c|}
\hline Variable & Type & Attributes & Analysis \\
\hline \multicolumn{4}{|l|}{ Relationship with the study area } \\
\hline Working in primary sector & binary & $\begin{array}{l}\text { respondents related to provisioning } \\
\text { activities in a direct way (farmers, } \\
\text { beekeepers, shepherds, fishermen, etc.) } \\
(1=\text { working in primary sector; } 0= \\
\text { other) }\end{array}$ & PCA \\
\hline Conservation interest & binary & $\begin{array}{l}\text { respondents with a high motivation for } \\
\text { wildlife and landscape conservation } \\
\text { (nature tourist, managers, } \\
\text { birdwatchers) }(1=\text { conservation } \\
\text { interest; } 0=\text { other) }\end{array}$ & PCA \\
\hline \multicolumn{4}{|c|}{ Perception of importance of ecosystem services } \\
\hline Ecosystem service & binary & $\begin{array}{l}\text { considers Doñana as a provider of } \\
\text { ecosystem services }(1=\text { Doñana } \\
\text { provides ecosystem services for human } \\
\text { well-being; } 0=\text { other })\end{array}$ & PCA \\
\hline Number of ecosystem services & ordinal & $\begin{array}{l}\text { number of ecosystem services recognized } \\
\text { as important in the area }\end{array}$ & $\begin{array}{l}\text { PCA } \\
\text { Heckman model (Probit and } \\
\text { ordinary least squares } \\
\text { [OLS]) }\end{array}$ \\
\hline \multicolumn{4}{|l|}{ Important ecosystem services } \\
\hline Provisioning & binary & $\begin{array}{l}\text { Doñana and its biodiversity play an } \\
\text { important role in the generation of } \\
\text { provisioning ecosystem services }(1= \\
\text { yes; } 0=\text { other })\end{array}$ & Heckman model (OLS) \\
\hline Water quality & binary & $\begin{array}{l}\text { Doñana and its biodiversity play an } \\
\text { important role in the provision of } \\
\text { water quality }(1=\text { yes; } 0=\text { other })\end{array}$ & $\begin{array}{l}\text { Heckman model (Probit and } \\
\text { OLS) }\end{array}$ \\
\hline Air quality & binary & $\begin{array}{l}\text { Doñana and its biodiversity play an } \\
\text { important role in the provision of air } \\
\text { quality }(1=\text { yes; } 0=\text { other })\end{array}$ & Heckman model (Probit) \\
\hline Climate regulation & binary & $\begin{array}{l}\text { Doñana and its biodiversity play an } \\
\text { important role in climate regulation }(1 \\
=\text { yes; } 0=\text { other })\end{array}$ & Heckman model (Probit) \\
\hline Soil quality & binary & $\begin{array}{l}\text { Donana and its biodiversity play an } \\
\text { important role in soil protection and } \\
\text { erosion regulation }(1=\text { yes; } 0=\text { other })\end{array}$ & Heckman model (Probit) \\
\hline $\begin{array}{l}\text { Individual satisfaction for } \\
\text { conserving biodiversity }\end{array}$ & binary & $\begin{array}{l}\text { Doñana plays an important role in } \\
\text { biodiversity conservation }(1=\text { yes; } 0= \\
\text { other })\end{array}$ & Heckman model (Probit) \\
\hline \multicolumn{4}{|l|}{ General environmental behavior } \\
\hline NGO $\dagger$ & binary & $\begin{array}{l}\text { member of environmental } \mathrm{NGO}=1 ; 0 \\
=\text { other }\end{array}$ & $\begin{array}{l}\text { Heckman model (Probit and } \\
\text { OLS) }\end{array}$ \\
\hline Recycling & ordinal & $\begin{array}{l}\text { recycling frequency }(1=\text { never; } 2= \\
\quad \text { seldom; } 3=\text { often; } 4=\text { always })\end{array}$ & PCA \\
\hline \multicolumn{4}{|l|}{ Sociodemographic variables } \\
\hline Distance & continuous & $\begin{array}{l}\ln (\text { distance from place of residence to the } \\
\text { questionnaire place) } \$\end{array}$ & $\begin{array}{l}\text { PCA } \\
\text { Heckman model (OLS) }\end{array}$ \\
\hline Education & ordinal & $\begin{array}{l}\text { education level }(1=\text { none; } 2=\text { primary; } \\
\quad 3=\text { secondary; } 4=\text { university })\end{array}$ & $\begin{array}{l}\text { PCA } \\
\text { Heckman model (Probit) }\end{array}$ \\
\hline Age & continuous & $\ln ($ age $) \S$ & $\begin{array}{l}\text { PCA } \\
\text { Heckman model (Probit and } \\
\text { OLS) }\end{array}$ \\
\hline Years familiar & continuous & $\begin{array}{l}\text { how long has been familiar with the } \\
\text { study area, living there, or visiting it } \\
\text { (years) }\end{array}$ & $\begin{array}{l}\text { PCA } \\
\text { Heckman model (Probit) }\end{array}$ \\
\hline House size & ordinal & household size (number of members) & $\begin{array}{l}\text { Heckman model (Probit and } \\
\text { OLS) }\end{array}$ \\
\hline Income & semi-continuous & $\begin{array}{l}\ln \text { (monthly family income, which reflects } \\
\text { the mid-point of six income intervals) }\end{array}$ & $\begin{array}{l}\text { Heckman model (Probit and } \\
\text { OLS) }\end{array}$ \\
\hline
\end{tabular}

$\dagger$ Nongovernmental organization.

$\$$ Measured in kilometers.

$\S$ Measured in years.

- Intervals are $0-900 €=600 € ; 900-1500 €=1200 € ; 1500-2100 €=1800 € ; 2100-2700 €=2400 € ; 2700-3300=3000 € ; \geq 3300 €=$ $3600 €(1 €=$ US\$ 1.37; average July 2008-March 2009). 
Chapin et al. (1996). We used exactly the same methodology for analyzing the social data (stakeholder group classification) that has been used in previous works (e.g., García-Llorente et al. 2011).

The variables used in the ESP and ESB analyses are shown in Tables 2 and 3, respectively. To explore the statistical differences between the traits describing the different ESPs, we used Kruskal-Wallis and ANOVA tests.

Willingness to pay (WTP) for ecosystem services provided by aquatic plant functional groups.-To assess the value assigned by different stakeholders to different ecosystem services, we used contingent valuation (CV), an economic valuation technique. This valuation technique is a stated preference method that elicits public preferences by directly asking people how much they would be willing to pay (or accept) for a change in the quantity or quality of a given environmental good or service in a hypothetical market (Mitchell and Carson 1989, Turner et al. 2010). The approach is known to have a number of limitations, especially when applied to environmental issues. For example, as based on neoclassical economics, CV assumes that individuals in a society have rational preferences, try to maximize their utility, and that social interest is an aggregation of individual interests (Dequech 2007). Other criticisms relate to the fact that willingness to pay (WTP) is unavoidably a function of ability to pay, which has implications for equity (Jorgensen et al. 2001), and it attempts to assign a monetary value to things that are considered to be incommensurate with monetary valuation (Pearce 2000, Aldred 2006). There is also a continuing debate regarding the suitability of $\mathrm{CV}$ for environmental decision-making because of possible biases arising from, for example, strategic responses, unfamiliarity or sequencing effects (Carson et al. 2001, Schläpfer 2008). However, the method provides abundant information relevant to designing conservation policies (Turner et al. 2010, García-Llorente et al. 2011), particularly when its WTP results are viewed as attitudes or social preferences rather than as indicators of economic preferences (Kahneman and Ritov 1999). Specifically in the case of ecosystem services, some authors have argued that CV should help detect and communicate changes in ecosystem service provision (Kontogianni et al. 2010, Pascual et al. 2010). In other words, it is argued that CV should be useful in highlighting the connections between the economic valuation of ecosystem services and the biological systems underpinning them, thus increasing the socalled "visibility of nature" in valuation (Sukhdev 2011). To our knowledge, this argument has not been tested in specific case studies. Therefore, we set out to test this proposition in the Doñana SES, being aware of both the limitations of the economic valuation technique and its widespread use.

An open-ended elicitation format was used to generate a more realistic and direct measure of the maximum WTP without a starting bid (which could influence respondent maximum WTP) (Bateman et al. 2002). A common problem in open-ended CV-bid analyses is a large number of responses with zero values (Mitchell and Carson 1989). This result is due to respondents choosing not to contribute (represented by zero monetary value) and a continuous positive distribution of WTP amounts for those respondents who were willing to contribute. When a dependent variable has a concentration of observations at a specific limit, conventional multiple regression is not an appropriate statistical method (Lee and Maddala 1985). In such cases, it is necessary to use a censored model, such as the Heckman model (Heckman 1979). The Heckman model uses two different equations: the first explains the respondent's decision to pay or not to pay through a probit regression, and the second explains the positive value of the WTP through ordinary least squares (Sigelman and Zeng 1999). The model maintains the assumption of dependence between the two decisions by analyzing the covariance between the error terms. Furthermore, the Heckman model assumes that a distribution for the second stage variable (the amount of WTP) exists but is not observed when the dependent variable is beyond a given threshold (e.g., when WTP < 0). Following Sigelman and Zeng (1999), the Heckman model is a response to sample selection bias, which arises when data are available only for cases in which a variable reflecting "pay," $z^{*}$, exceeds zero. For more details about the Heckman model, see Martín-López et al. (2007) and García-Llorente et al. (2008). The variables used in the Heckman model are presented in Table 3.

We censored WTP results using the Kaplan-Meier survival curve when the probability of the respondents agreeing to give money was less than $2 \%$ and when the questionnaire was incomplete (Bateman et al. 2002). In total, 404 questionnaires were used in the economic valuation exercise. The results obtained from the Heckman model were analyzed by ANOVA to determine the influence of the ecosystem services categories on WTP. Finally, the results generated by the Heckman model were analyzed using canonical correspondence analysis (CCA) to ascertain the noneconomic factors that influenced WTP and how they were related to ESBs and ESPs.

\section{RESUlts}

\section{ESPS: aquatic plant functional groups with different potentials to contribute to ecosystem properties and services}

Seven functional groups were obtained by applying multivariate analyses $(76.47 \%$ of dissimilarity in the cluster analysis) to the 144 plant species by a data set of 16 functional traits (Fig. 3 and Appendix C). The ordination of species by their traits using PCA produced eight factors with eigenvalues higher than one, explaining $72.09 \%$ of the variation in the attribute data 


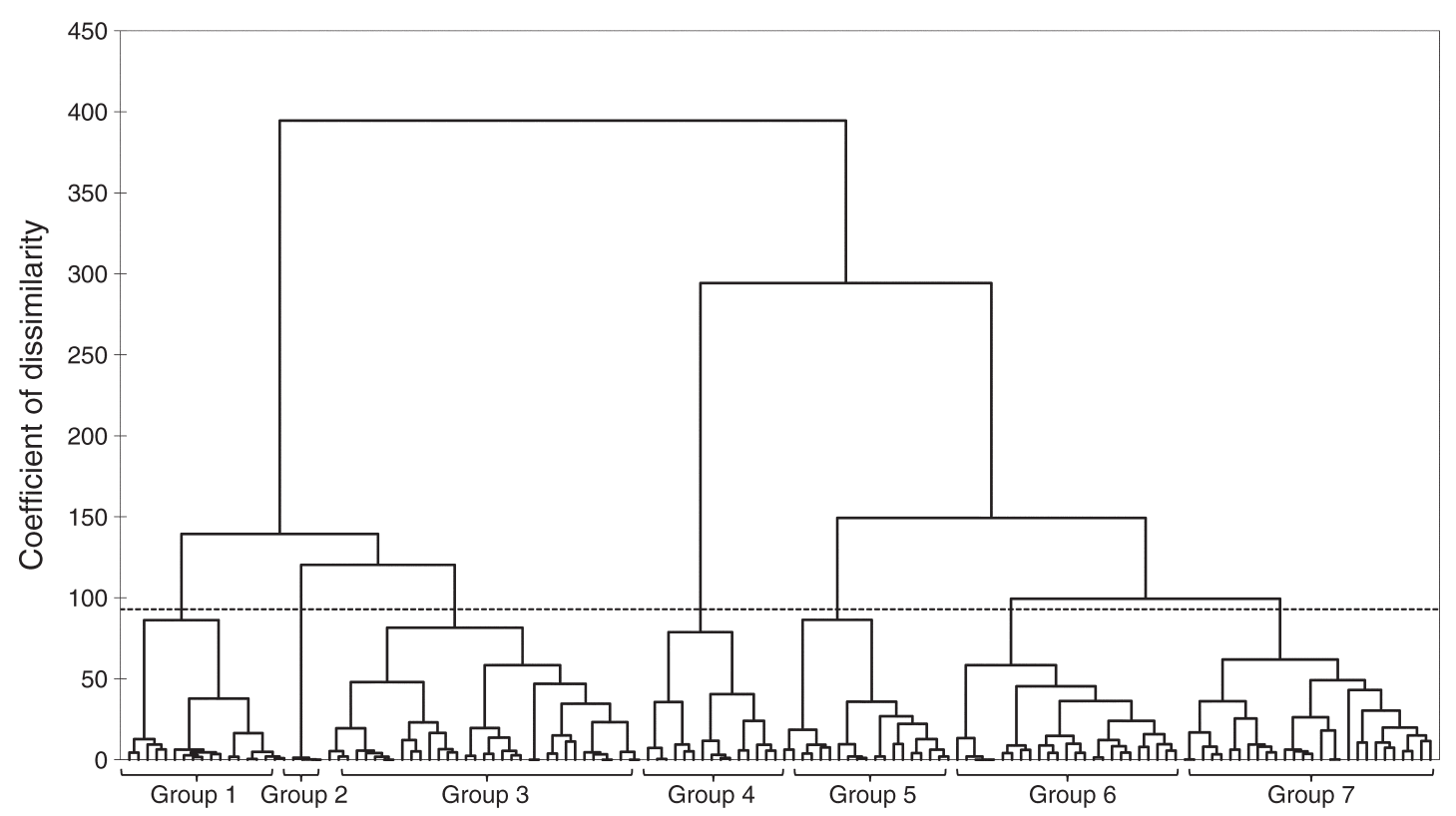

FIG. 3. Cluster analysis of aquatic plant functional groups (ESPs) defined on the basis of the 16 functional traits listed in Table 2.

(Appendix D). Thus, the functional groups obtained represent species with different functional trait values which, therefore, should be able to provide different ecosystem services. The characteristics of the seven ESP groups are shown in Table 4. These, together with their links to the ecosystem properties and services presented in Table 1, are summarized below. Note that the characteristics of each group define the majority of its members but do not necessarily apply strictly to every single species in the group.

Group 1.-Small-statured sedges and rushes that require root submersion during at least part of the year and salt-tolerant chenopods that tolerate (but do not necessarily require) temporal root submersion. In general, members of Group 1 have dense root systems that contribute to soil formation and fertility. Their leaf texture (in the cases of Juncaceae and Cyperaceae) and plant height make them very suitable for consumption by livestock (see Table 1).

Group 2.-Small-statured, perennial fern allies (quillworts); they have a single basal growth point, small leaves, no obvious physical defenses, and reproduce only by spores. The early phenology and characteristic underground bulb-like rhizomes are related to a peak primary productivity early in the season, which should facilitate the temporal continuity of primary production during droughts that tend to occur later in the season. Their dispersion of spores by water should facilitate the in-situ perpetuation of these species as well as their distribution throughout the landscape (see Table 1).

Group 3.-Emergent swamp plants, mostly rushes and sedges, generally perennial, with tough leaves, low body flexibility, large stature, rhizomes, visually attractive foliage, and wind-dispersed propagules (Table 4). Some of these perennial species develop dense networks of rhizomes and roots that can influence the physicochemical characteristics of the sediment, contributing to soil formation and fertility. The tall stature of this group should contribute to bird habitat (see Plate 1). In terms of cultural values, some of these species have aesthetic value associated with their foliage, which is visually attractive from autumn to winter. Traditionally, they have been used as basketwork material (see Table 1).

Group 4.-Free-floating (on the water surface or submerged) plants, generally with small leaves and small, water-dispersed dispersules and multiple apical meristems; they spread by stolons and show early phenology. Their body flexibility protects them against ungulate trampling, and their early phenology should help maintain primary productivity as is the case of Group 2. A number of medicinal properties are associated with this group; for example, Lemna minor leaves are used to treat intestinal inflammation.

Group 5.- Submerged plants anchored to the sediment, generally with multiple apical meristems, rhizomes, early phenology, and dispersal by water. Their leaf texture and vertical shoot architecture are indicative of fast growth and high tissue quality, which should provide suitable bird forage and contribute to macronutrient recycling and soil formation and fertility. The early phenology of these species should help maintain primary productivity during seasonal droughts. Additionally, because of their rhizomes, some of these species likely contribute to water filtration and the retention of suspended matter, resulting in enhanced water quality.

Group 6.-Plants anchored to the sediment with vertical roots, some of them with emergent leaves; others completely submerged, with multiple apical 
TABLE 4. Characterization of the seven aquatic plant functional groups (ESPs) generated by cluster analyses, including KruskalWallis (KW) and ANOVA (A) tests.

\begin{tabular}{|c|c|c|c|c|}
\hline \multirow[b]{2}{*}{ Variables } & \multicolumn{4}{|c|}{ Ecosystem services provider groups (percentage of species) } \\
\hline & Group $1(12.5 \%)$ & Group $2(2.8 \%)$ & Group $3(24.3 \%)$ & Group $4(10.4 \%)$ \\
\hline Prominent families $\dagger$ & $\begin{array}{l}\text { Juncaceae, Cyperaceae, } \\
\text { Chenopodiaceae }\end{array}$ & Isoetaceae & $\begin{array}{l}\text { Cyperaceae, } \\
\text { Juncaceae }\end{array}$ & $\begin{array}{l}\text { Ruppiaceae, Riellaceae, } \\
\text { Lemnaceae }\end{array}$ \\
\hline Ecosystem & $\begin{array}{l}\text { ponds on aeolian sheets, } \\
\text { freshwater marshes }\end{array}$ & $\begin{array}{l}\text { ponds on aeolian } \\
\text { sheets }\end{array}$ & $\begin{array}{l}\text { freshwater marshes, } \\
\text { streams on } \\
\text { aeolian sheets }\end{array}$ & $\begin{array}{l}\text { ponds on aeolian } \\
\text { sheets, salt marshes, } \\
\text { freshwater marshes }\end{array}$ \\
\hline \multicolumn{5}{|l|}{ Aquatic growth form } \\
\hline Floating & $0.00 \%$ & $0.00 \%$ & $0.00 \%$ & $86.30 \%$ \\
\hline Anchored, submerged leaves & $0.00 \%$ & $0.00 \%$ & $0.00 \%$ & $13.33 \%$ \\
\hline Anchored, emergent leaves & $11.11 \%$ & $0.00 \%$ & $8.60 \%$ & $0.00 \%$ \\
\hline Halophytes & $88.89 \%$ & $0.00 \%$ & $42.86 \%$ & $46.67 \%$ \\
\hline Helophytes & $0.00 \%$ & $100.00 \%$ & $91.40 \%$ & $0.00 \%$ \\
\hline Life span: perennial & $55.56 \%$ & $100.00 \%$ & $88.57 \%$ & $66.67 \%$ \\
\hline Plant height (mean in $\mathrm{cm}$ ) & 28.97 & 28.00 & 100.41 & 19.51 \\
\hline Body flexibility & $\begin{array}{l}\text { low (Chenopodiaceae), } \\
\text { intermediate } \\
\text { (Cyperaceae, Juncaceae) }\end{array}$ & low & low & intermediate \\
\hline Early phenology & $22.22 \%$ & $100.00 \%$ & $54.28 \%$ & $60.00 \%$ \\
\hline \multicolumn{5}{|l|}{ Vertical shoot architecture } \\
\hline Single apical meristem & $0.00 \%$ & $0.00 \%$ & $31.43 \%$ & $0.00 \%$ \\
\hline Single basal meristem & $66.67 \%$ & $100 \%$ & $31.43 \%$ & $26.67 \%$ \\
\hline Multiple apical meristem & $33.33 \%$ & $0.00 \%$ & $37.14 \%$ & $73.33 \%$ \\
\hline Leaf area (mean, in $\left.\mathrm{cm}^{2}\right)$ & 5.36 & 5.05 & 41.49 & 1.89 \\
\hline Leaf texture & $\begin{array}{l}\text { tough (Chenopodiaceae), } \\
\text { intermediate } \\
\text { (Cyperaceae, Juncaceae) }\end{array}$ & tough & tough & $\begin{array}{l}\text { intermediate between } \\
\text { soft and tough }\end{array}$ \\
\hline Physical defenses & $72.22 \%$ & $0.00 \%$ & $74.29 \%$ & $6.67 \%$ \\
\hline \multicolumn{5}{|l|}{ Root type } \\
\hline Simple root & $50.00 \%$ & $0.00 \%$ & $5.71 \%$ & $6.67 \%$ \\
\hline Rhizomes/tubers/bulbs & $50.00 \%$ & $100.00 \%$ & $88.57 \%$ & $6.67 \%$ \\
\hline Stolons & $0.00 \%$ & $0.00 \%$ & $11.43 \%$ & $80.00 \%$ \\
\hline Dispersule size (mean in $\mathrm{mm}$ ) & 0.82 & 0.03 & 1.88 & 0.84 \\
\hline Dispersule shape (unitless) & 0.04 & 0.01 & 0.05 & 0.02 \\
\hline \multicolumn{5}{|l|}{ Dispersal mode } \\
\hline Wind & $100.00 \%$ & $0.00 \%$ & $74.28 \%$ & $13.33 \%$ \\
\hline Water & $0.00 \%$ & $100.00 \%$ & $8.57 \%$ & $53.33 \%$ \\
\hline Animal & $0.00 \%$ & $0.00 \%$ & $20.00 \%$ & $20.00 \%$ \\
\hline Vegetative reproduction & only by seed & only by spores & $\begin{array}{l}\text { vegetative and seed } \\
\text { reproduction }\end{array}$ & $\begin{array}{l}\text { only by seed or spores } \\
\text { or only vegetative } \\
\text { reproduction }\end{array}$ \\
\hline Flower visually attractive & $11.11 \%$ & $0.00 \%$ & $8.57 \%$ & $13.33 \%$ \\
\hline Foliage visually attractive & $22.22 \%$ & $0.00 \%$ & $42.86 \%$ & $0.00 \%$ \\
\hline
\end{tabular}

$* * P<0.01$.

$\dagger$ Family representing more than $20 \%$ of the species in each group.

$\$$ Heterogeneous functional group with several families (e.g., Potamogetonaceae, Scrophulariaceae, Ranunculaceae, Poaceae, Lamiaceae, Polygonaceae, or Haloragaceae), none of which represented $10 \%$ or more species.

meristems and simple roots anchored to the sediment with submerged and emergent leaves. Some of the species with emergent leaves (e.g., Ranunculus spp., Callitriche spp.) have the potential to provide habitat for aquatic invertebrates. Their leaf texture and vertical shoot architecture are indicative of fast growth and high tissue quality, which should favor macronutrient recycling and soil formation and fertility. The early phenology, small seed size, and seed shape are associated with persistence in the soil seed bank and peak primary productivity early in season. Both of these properties should favor the temporal continuity of primary production during disturbance events and seasonal droughts. Finally, the visually attractive flowers of some of the species in this group, such as Ranunculus spp., Alisma spp., and Apium spp., provide recreational and aesthetic services.

Group 7.- Plants anchored to the sediment with horizontal roots, some of them with emergent leaves, others completely submerged; mostly perennial, with visually attractive flowers that enhance the aesthetic value of the habitat. Their spread through horizontal roots should contribute to runoff retention and hence to water regulation. Some of the species in this group are used directly as a source of food (Lythrum salicaria and Glyceria fluitans). 
TABLE 4. Extended.

\begin{tabular}{|c|c|c|c|}
\hline \multicolumn{3}{|c|}{ Ecosystem services provider groups (percentage of species) } & \multirow[b]{2}{*}{ Test } \\
\hline Group $5(13.2 \%)$ & Group $6(17.4 \%)$ & Group $7(19.4 \%)$ & \\
\hline $\begin{array}{l}\text { Ranunculaceae } \\
\text { ponds on aeolian sheets, } \\
\text { freshwater marshes }\end{array}$ & $\begin{array}{l}\text { Ranunculaceae, } \\
\text { Callitrichaceae, Elatinaceae } \\
\text { ponds on aeolian sheets, } \\
\text { freshwater marshes }\end{array}$ & $\begin{array}{l}\text { lack of prominent families } \neq \\
\text { ponds on the aeolian sheets, } \\
\text { freshwater marshes, streams } \\
\text { on aeolian sheets }\end{array}$ & \\
\hline $\begin{array}{l}0.00 \% \\
31.58 \% \\
5.26 \% \\
42.11 \% \\
0.00 \% \\
42.10 \% \\
28.95 \\
\text { intermediate }\end{array}$ & $\begin{array}{l}0.00 \% \\
92.00 \% \\
80.00 \% \\
16.00 \% \\
0.00 \% \\
28.00 \% \\
50.00 \\
\text { intermediate }\end{array}$ & $\begin{array}{l}0.00 \% \\
85.71 \% \\
57.14 \% \\
7.14 \% \\
0.00 \% \\
89.29 \% \\
53.07 \\
\text { intermediate }\end{array}$ & $\begin{array}{l}\chi^{2}=143^{* *}(\mathrm{KW}) \\
\chi_{2}^{2}=97.39^{* *}(\mathrm{KW}) \\
\chi_{2}=70.81^{* *}(\mathrm{KW}) \\
\chi_{2}^{2}=23.16^{* *}(\mathrm{KW}) \\
\chi^{2}=122.89^{* *}(\mathrm{KW}) \\
\chi^{2}=38.29^{* *}(\mathrm{KW}) \\
F_{6,137}=14^{* *}(\mathrm{~A}) \\
\chi^{2}=40.49^{* *}(\mathrm{KW})\end{array}$ \\
\hline $68.42 \%$ & $64.00 \%$ & $42.85 \%$ & $\chi^{2}=14.80^{* *}(\mathrm{KW})$ \\
\hline $\begin{array}{l}15.79 \% \\
21.05 \% \\
63.16 \% \\
3.13 \\
\text { intermediate between soft } \\
\quad \text { and tough }\end{array}$ & $\begin{array}{l}16.00 \% \\
24.00 \% \\
60.00 \% \\
19.00 \\
\text { intermediate between soft } \\
\quad \text { and tough }\end{array}$ & $\begin{array}{l}7.14 \% \\
14.28 \% \\
78.57 \% \\
10.77 \\
\text { intermediate between soft } \\
\quad \text { and tough }\end{array}$ & $\begin{array}{l}\chi^{2}=16.07(\mathrm{KW}) \\
\chi^{2}=24.56^{* *}(\mathrm{KW}) \\
\chi^{2}=21.73^{* *}(\mathrm{KW}) \\
F_{6,137}=16.28^{* *}(\mathrm{~A}) \\
\chi^{2}=35.40^{* *}(\mathrm{KW})\end{array}$ \\
\hline $57.89 \%$ & $56.00 \%$ & $75.00 \%$ & $\chi^{2}=43.95^{* *}(\mathrm{KW})$ \\
\hline $\begin{array}{l}10.53 \% \\
78.95 \% \\
0.00 \%\end{array}$ & $\begin{array}{l}64.00 \% \\
8.00 \% \\
4.00 \%\end{array}$ & $\begin{array}{l}10.71 \% \\
57.14 \% \\
53.57 \%\end{array}$ & $\begin{array}{l}\chi_{2}^{2}=44.36^{* *}(\mathrm{KW}) \\
\chi^{2}=59.67 * *(\mathrm{KW}) \\
\chi^{2}=63.33^{* *}(\mathrm{KW})\end{array}$ \\
\hline $\begin{array}{l}3.49 \\
0.05\end{array}$ & $\begin{array}{l}1.54 \\
0.04\end{array}$ & $\begin{array}{l}3.17 \\
0.06\end{array}$ & $\begin{array}{l}F_{6,137}=11.61^{* *}(\mathrm{~A}) \\
F_{6,137}=1.84(\mathrm{~A})\end{array}$ \\
\hline $\begin{array}{l}26.31 \% \\
57.89 \% \\
31.59 \% \\
\text { vegetative and seed } \\
\quad \text { reproduction }\end{array}$ & $\begin{array}{l}4.00 \% \\
4.00 \% \\
48.00 \% \\
\text { vegetative and seed } \\
\quad \text { reproduction }\end{array}$ & $\begin{array}{l}71.43 \% \\
14.28 \% \\
39.28 \% \\
\text { vegetative and seed } \\
\quad \text { reproduction }\end{array}$ & $\begin{array}{l}\chi^{2}=68.41 * *(\mathrm{KW}) \\
\chi^{2}=51.91 * *(\mathrm{KW}) \\
\chi_{2}^{2}=17.17 * *(\mathrm{KW}) \\
\chi^{2}=42.72 * *(\mathrm{KW})\end{array}$ \\
\hline $\begin{array}{l}42.10 \% \\
0.00 \%\end{array}$ & $\begin{array}{l}60.00 \% \\
4.00 \%\end{array}$ & $\begin{array}{l}75.00 \% \\
7.14 \%\end{array}$ & $\begin{array}{l}\chi^{2}=28.47 * *(\mathrm{KW}) \\
\chi^{2}=31.76^{* *}(\mathrm{KW})\end{array}$ \\
\hline
\end{tabular}

\section{ESBs: stakeholder groups with different ecosystem service demands}

Three factors derived from the PCA characterized the relationship of the ESBs with the study area: relation with the Doñana SES, sociodemographic characteristics, and perception of the importance of ecosystem services (Appendix E). Factor 1 (27.23\% of variance explained) was associated with items that represented respondents' relationship with the Doñana SES, such as their motivation to be there (i.e., working in primary sector and conservation interest), the distance from their place of residence to the study area, and their familiarity with Doñana. The variables conservation interest and distance were related to positive loadings, whereas working in primary sector and years of familiarity with the study area (years familiar for short) were related to negative loadings. Respondents who traveled to the area from greater distances were more likely to consider the conservation values of the natural area, whereas respondents living in or near the area were more likely to benefit from the provisioning of ecosystem services generated by agricultural fields. The items loading on Factor $2(17.66 \%)$ were related to the respondents' sociodemographic characteristics. This latent variable was interpreted in terms of age and education level variables, with younger respondents being associated with higher levels of education. Finally, Factor 3 $(15.42 \%)$ was associated with items related to the ecosystem services provided by Doñana SES. The variables that contributed most to this factor (in the positive loadings) were the recognition of the Doñana 


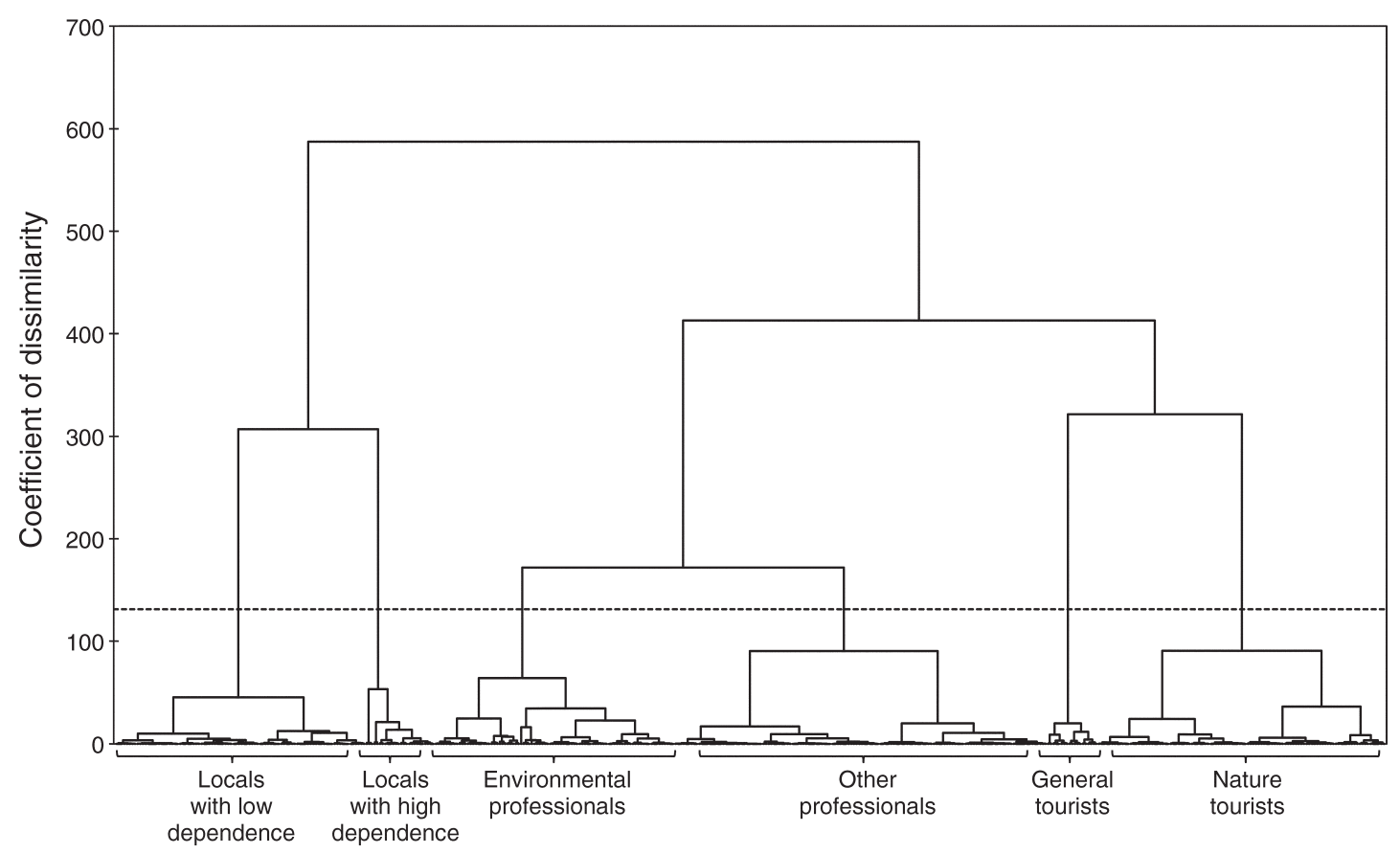

FIG. 4. Cluster analysis of ESBs on the basis of respondents' relationships with the study area, ecosystem service dependence and perceptions, general environmental behaviors, and sociodemographic characteristics.

ecosystem supplying services and the number of ecosystem services provided.

The cluster analysis conducted $(77.65 \%$ of dissimilarity) with the latent factors obtained from the PCA indicated the existence of six ESBs: locals with low dependence on provisioning ecosystem services (19.7\%), locals with high dependence (5.5\%), environmental professionals (18.9\%), other professionals (29.4\%), general tourists (4.0\%), and nature tourists (22.6\%) (Fig. 4).

A more detailed characterization of the ESBs can be seen in Table 5. Local users were respondents whose residence was within the Doñana SES and whose environmental behavior, level of education, and income were the lowest. We identified two groups of locals: locals with high dependence on provisioning ecosystem services and locals with low dependence. Both groups recognized the importance of Doñana as a provider of ecosystem services $(100 \%$ and $88 \%$ of locals with low and high dependence, respectively). However, locals with high dependence were, in particular, individuals whose work depended directly on provisioning services, such as fishermen, beekeepers, crayfish fishermen, seafood collectors, rice farmers, and farmers practicing other forms of agriculture, therefore this group was actually expressing a utilitarian relationship with provisioning services. They also recognized air quality, individual satisfaction for conserving biodiversity, and tourism as the most important services. Finally, they named conservation interest and their jobs being linked to working in primary sector as motivations for living there. In contrast, locals with low dependence had a minor relationship with provisioning services. They selected air quality, individual satisfaction for conserving biodiversity, and environmental education as important ecosystem services.

Environmental professionals and other professionals had the highest levels of education in our sample, and most of these individuals were involved in management or research on the Doñana SES or were interested in conservation. Air quality, environmental education, and individual satisfaction related to conserving biodiversity were the most important ecosystem services for both of these groups. The difference between them was that environmental professionals expressed an interest in nature conservation and presented higher environmental behavior (in terms of the number of protected areas visited and their membership in environmental nongovernmental organizations). Furthermore, environmental professionals differed from other groups because they named a larger number of examples regarding the services provided in the area in response to the open question (Table 5).

Both groups of tourists traveled from longer distances, had the lowest familiarity with the study area (less than 5 years living there or visiting it), as compared with other stakeholders, and were there because of conservation motivations. The major difference between the two groups of tourist was in their concern about the ecosystem services supplied by Doñana ecosystems. General tourists were the only group unable to provide any examples of ecosystem services provided in the area 
in the open question. In fact, in the first question, regarding whether they considered Doñana as an ecosystem service provider area, they revealed a complete lack of knowledge. Nature tourists enjoyed different activities in nature and were environmentally aware. In contrast to locals, nature tourists only recognized regulating and cultural services. Interestingly, the only ecosystem service considered important by all ESBs was individual satisfaction for conserving biodiversity, i.e., the existence value (Table 5).

\section{Economic valuation estimations}

Of the total respondents, $38.3 \%$ in the economic valuation exercise refused to pay. Zero values were recorded for $9.84 \%$ of them (reflecting an indifference as to whether or not an ecosystem service was provided), and the remaining $28.46 \%$ provided protest responses (reflecting respondents' protesting against the valuation scenario). Particularly, local users provided the highest percentage of protest responses, followed by tourists and professionals (for more details, see García-Llorente et al. 2011).

We found eight significant variables explaining the probability of participation in the economic valuation exercise in the probit regression (Table 6). The variables number of ecosystem services, water quality, soil quality, individual satisfaction for conserving biodiversity, and NGO were positive and statistically significant, whereas provisioning services, years familiar, and age were negative. Respondents who recognized the contribution of regulating and cultural services to their well-being and respondents with a high degree of awareness of environmental issues had a higher probability of participating in the economic valuation exercise. Furthermore, younger respondents were more aware of issues pertaining to ecosystem services than older respondents and were more willing to participate, and younger respondents also had a lower degree of familiarity with the study area. Thus, respondents who had been living in the area all their lives or for long periods, as well as respondents dependent on provisioning services, were less willing to participate.

In the second stage of the Heckman model (Table 6), we found five statistically significant and positive variables: distance, number of ecosystem services, water quality, individual satisfaction for conserving biodiversity, and NGO; age was a negative variable. A higher level of awareness of environmental issues promoted an interest in supporting ecosystem services delivery, reflected in higher WTP. Additionally, respondents who traveled greater distances to visit Doñana were more likely to have higher WTP than residents. Finally, younger respondents who recognized the importance of ecosystem services contributed higher amounts.

An analysis of the economic contributions considering the different ESBs showed differences in the overall mean WTP among them (ANOVA, $F_{5,398}=8.709, P<$ 0.01). The ESBs who contributed higher amounts were both groups of professionals, followed by tourists and local users (Table 7). The attitudes surrounding WTP for ecosystem services delivery showed that the total sample was more willing to contribute to regulating services (i.e., soil formation and fertility, water purification) than to provisioning services (i.e., direct source of food, medicinal value). Recreational-aesthetic services received the lowest support (Table 7 ).

Different relationships between the ESBs and their WTP for particular ecosystem services were also found in the CCA (Fig. 5; Appendix F). Factor 1 captured indirect use values vs. direct use values (in the sense of Pearce and Turner 1990), i.e., the values derived from regulating services vs. values resulting from the direct use of aquatic plants. The ecosystem services with positive loadings were related to direct use values, such as cultural and provisioning services, whereas the negative loadings were associated with indirect use values (i.e., regulating services). Nature tourists and local users with high and low dependence were associated with direct use values, whereas environmental professionals and other professionals were associated with indirect use values (soil formation and fertility and habitat and food for birds, respectively). Factor 2 captured extractive uses vs. non-extractive uses. Nature tourists were associated with non-extractive values, such as the recreational-aesthetic services provided by the aquatic plants. Locals were related to WTP for provisioning services. These results point to a clear link between ESBs and the type of ecosystem service valued, but no clear evidence of a relationship between ESPs and ESBs.

\section{Discussion}

In this study, we simultaneously considered both dimensions of ecosystem services: ecological (ESPs) and socioeconomic (ESBs) aspects of the aquatic ecosystems of Doñana. In recent decades, and more recently since the European Water Framework Directive (Council of the European Communities 2000), the number of studies regarding aquatic plants in Europe has increased. Particularly, a number of studies have focused on the characterization of macrophyte diversity in a particular area (e.g., Ferreira and Aguiar 2006, Hrivnák et al. 2006) or the relationships between macrophytes and environmental conditions for the creation of water quality indices (e.g., Meilinger et al. 2005, Stelzer et al. 2005, Coops et al. 2007). Willby et al. (2000) is the only study we are aware of that classifies European hydrophytes on the basis of homogeneous sets of traits, but it does not link this information with the functions of these aquatic plants or their delivery of ecosystem services. Engelhardt (2006) associated aquatic plant functional traits with multiple ecosystem functions but not with ecosystem service delivery. In the present study, we classified Doñana SES aquatic plants on the basis of their functional traits into seven functional groups (ESPs) with different capacities to contribute to the 
TABLE 5. Characterization of the six ecosystem service beneficiaries (ESBs) generated by cluster analysis.

\begin{tabular}{|c|c|c|c|}
\hline \multirow[b]{2}{*}{ ESBs $(\%)$} & \multicolumn{3}{|c|}{ Perception of importance of ecosystem services } \\
\hline & $\begin{array}{l}\text { Ecosystem } \\
\text { services } \\
\text { provided }(\%)\end{array}$ & $\begin{array}{l}\text { Ecosystem services } \\
\text { known } \dagger\end{array}$ & $\begin{array}{l}\text { Important ecosystem } \\
\text { services } \ddagger\end{array}$ \\
\hline $\begin{array}{l}\text { Locals with low } \\
\text { dependence }(19.7 \%)\end{array}$ & 100 & air quality, tourism & $\begin{array}{l}\text { individual satisfaction for conserving } \\
\text { biodiversity, || air quality, } \\
\text { environmental education }\end{array}$ \\
\hline $\begin{array}{l}\text { Locals with high } \\
\text { dependence }(5.5 \%)\end{array}$ & 88 & $\begin{array}{l}\text { agriculture, timber, tourism, fish and } \\
\text { shellfish, air quality }\end{array}$ & $\begin{array}{l}\text { provisioning, tourism, individual } \\
\text { satisfaction for conserving } \\
\text { biodiversity, || air quality }\end{array}$ \\
\hline $\begin{array}{l}\text { Environmental } \\
\text { professionals }(18.9 \%)\end{array}$ & 100 & $\begin{array}{l}\text { tourism, relaxation and tranquility, } \\
\text { individual satisfaction for conserving } \\
\text { biodiversity, || aesthetic value, air quality, } \\
\text { environmental education, agriculture }\end{array}$ & $\begin{array}{l}\text { individual satisfaction for conserving } \\
\text { biodiversity,\| environmental } \\
\text { education, air quality }\end{array}$ \\
\hline $\begin{array}{l}\text { Other professionals } \\
(29.4 \%)\end{array}$ & 100 & air quality, tourism & $\begin{array}{l}\text { individual satisfaction for conserving } \\
\text { biodiversity, || environmental } \\
\text { education, air quality }\end{array}$ \\
\hline General tourists $(4.0 \%)$ & 0 & & $\begin{array}{l}\text { climate regulation, individual satisfaction } \\
\text { for conserving biodiversity, „| } \\
\text { environmental education, air quality }\end{array}$ \\
\hline Nature tourists $(22.6 \%)$ & 100 & $\begin{array}{l}\text { individual satisfaction for conserving } \\
\text { biodiversity, || tourism, aesthetic value, air } \\
\text { quality }\end{array}$ & $\begin{array}{l}\text { individual satisfaction for conserving } \\
\text { biodiversity,|| environmental } \\
\text { education, climate regulation }\end{array}$ \\
\hline
\end{tabular}

$\dagger$ Ecosystem services named by more than $5 \%$ of the stakeholders in each category as examples in the area in an open question.

$\$$ Ecosystem services selected from the list by more than $50 \%$ of the stakeholders in each category.

$\S$ Motivation to be involved with the study area selected by more than $10 \%$ of the stakeholders in each category.

- Place of residence for more than $20 \%$ of the stakeholders in each category.

$\# 1 €=$ US\$ 1.37; average July 2008-March 2009.

I| Related to the satisfaction of knowing about the existence of species, even in cases in which these species are unseen.

provision of ecosystem services. We then classified the beneficiaries of ecosystem services (ESBs) according to their relationships with the study area, their perceptions of the importance of ecosystem services, and their sociodemographic characteristics, following previous studies by Martín-López et al. (2007) and GarcíaLlorente et al. (2008).

Our results suggest that all ESBs were aware of the importance of protecting biodiversity. We found that all of them recognized the individual satisfaction of conserving biodiversity as one of the most important ecosystem services of Doñana's aquatic ecosystems. Furthermore, biodiversity was one of the explanatory variables in the economic exercise. In other words, respondents who perceived the importance of Doñana's biodiversity were also more willing to participate in the economic exercise and more willing to contribute higher hypothetical amounts of money. Preferences for an array of ecosystem services associated with biodiversity had been studied previously, and the results agree with those of our study in pointing to regulating services as significantly more important to the more educated respondents than the other services (Sodhi et al. 2010). In contrast, ecosystem services associated with recreational and aesthetic values appear to be the least important (Montgomery 2002). In our results, attitudes related to WTP for sustaining services showed the same trend: respondents were more willing to pay for regulating than for provisioning services; the cultural services received the lowest support. We also found that ESBs who contributed with higher amounts were both groups of professionals, followed by tourists and local users. It is interesting to note that even local users gave higher hypothetic donations to regulating services than to provisioning services. This statement, along with the fact that local users exhibited a less favorable response to the hypothetical market through higher rates of protest answers (for more details, see García-Llorente et al. 2011) could be related to a reaction of locals toward paying more for ecosystem services with direct extractive value and a local opposition toward conservation policies (Elbersen 2001, García-Llorente et al. 2011). In summary, we found that the respondents were concerned about biodiversity conservation, and they were also aware of the importance of different ecosystem services-regulating services in particular-for their welfare. However, as we show below, they did not necessarily make connections between biodiversity and the continued delivery of these services.

Mainstream ecosystem service valuation is dominated by economic evaluation techniques. In general, these have shown low sensitivity to the ecosystem properties and components of biodiversity that underpin the different ecosystem services (Vatn and Bromley 1994, Kontogianni et al. 2010, Spangenberg and Settele 2010). According to some authors (e.g., Barkmann et al. 2008, Kontogianni et al. 2010), this limitation could be overcome by the explicit identification of ecosystem 
TABLE 5. Extended.

\begin{tabular}{|c|c|c|c|c|c|c|c|}
\hline \multicolumn{2}{|c|}{ Relationship to the study area } & \multirow{2}{*}{\multicolumn{3}{|c|}{ Environmental behavior }} & \multirow{2}{*}{\multicolumn{3}{|c|}{ Sociodemographic variables }} \\
\hline \multirow{2}{*}{$\begin{array}{l}\text { Years familiar } \\
\text { with the study area, } \\
\text { living there or } \\
\text { visiting it }(\mathrm{yr})\end{array}$} & \multirow[b]{2}{*}{$\begin{array}{l}\text { Motivation to be } \\
\text { in the study area } \S\end{array}$} & & & & & & \\
\hline & & $\begin{array}{l}\text { Protected } \\
\text { area }(\%)\end{array}$ & $\begin{array}{l}\mathrm{NGO} \\
(\%)\end{array}$ & Recycling & $\begin{array}{l}\text { Place of } \\
\text { residence }\end{array}$ & Education & Income\# \\
\hline always & $\begin{array}{l}\text { management or } \\
\text { research }\end{array}$ & 32 & 6 & often & Doñana & $\begin{array}{l}\text { primary, } \\
\text { secondary }\end{array}$ & $\begin{array}{c}0-900 €, 900- \\
1500 €\end{array}$ \\
\hline always & $\begin{array}{l}\text { working in primary } \\
\text { sector, } \\
\text { conservationist } \\
\text { interest }\end{array}$ & 42 & 19 & often & Doñana & $\begin{array}{l}\text { primary, } \\
\text { secondary }\end{array}$ & $\begin{array}{l}0-900 €, 900- \\
1500 €\end{array}$ \\
\hline$>10 \mathrm{yr}$ & $\begin{array}{l}\text { management or } \\
\text { research }\end{array}$ & 79 & 30 & $\begin{array}{l}\text { often-- } \\
\text { always }\end{array}$ & $\begin{array}{l}\text { Huelva-Seville- } \\
\text { Cádiz, Spain }\end{array}$ & university & $900-1500 €$ \\
\hline$>10 \mathrm{yr}$ & $\begin{array}{l}\text { management or } \\
\text { research }\end{array}$ & 58 & 9 & $\begin{array}{l}\text { often-- } \\
\text { always }\end{array}$ & $\begin{array}{l}\text { Doñana, Huelva- } \\
\text { Seville-Cádiz, } \\
\text { Spain }\end{array}$ & university & $\begin{array}{c}0-900 €, 900- \\
1500 €\end{array}$ \\
\hline$<5 \mathrm{yr}$ & conservationist interest & 32 & 5 & $\begin{array}{l}\text { often-- } \\
\quad \text { always }\end{array}$ & $\begin{array}{l}\text { Spain, Europe, } \\
\text { and America }\end{array}$ & secondary & $900-1500 €$ \\
\hline$<5 \mathrm{yr}$ & conservationist interest & 68 & 24 & always & $\begin{array}{l}\text { Spain, Europe, } \\
\text { and America }\end{array}$ & secondary & $\begin{array}{l}900-1500 € \\
1500-2100 €\end{array}$ \\
\hline
\end{tabular}

properties and their providers and their formal inclusion in the economic valuation process. We tested this approach and found that, in general, respondents failed to identify associations between the ecosystem services they valued and the ESPs (aquatic plant functional groups) with the best potential to provide them. Respondents' economic valuation of ecosystem services tended to ignore the ecosystem functions and biodiversity behind them even when thorough information on these functions was incorporated into the exercise. Therefore, at least in the case study analyzed, the explicit incorporation of ESPs did not substantially increase the "visibility" of components of biodiversity or ecosystem properties underlying ecosystem services in the economic valuation of these services.

What are the causes for this apparent failure to improve the visibility of nature (sensu Sukhdev 2011) in ecosystem service valuation? Although our study case was clearly not designed to formally reject rival explanations, some reasons for this disconnect can be proposed. First, the SES studied may involve peculiar circumstances (ecosystem services, elements of biodiversity, beneficiaries) that make it an exception and we cannot rule this out with only one case study. In particular, Doñana SES is an example of the conservation against development model (Folke 2006), which is based on protecting biodiversity inside the protected area and allowing land use intensification surrounding its borders (Martín-López et al. 2011). The restricted access to some of the ecosystem services traditionally used by local stakeholders inside the protected area promotes a mismatch between social and ecological systems. Additional contributing factors may be that the links between some of the services and the ESPs, and the differences among some of the ESPs, are arguably too subtle for some ESBs to recognize. A second explanation lies in the fact that in this case, both ecosystem services and the traits that make some ESPs more suitable than others for the provision of those services were pre-defined by the researchers. Although this is still the most common practice, the categories defined by the researchers might not have been fully compatible with those of the ESBs, and the causal links explained to respondents might not have been fully clear to them or might have been too novel to have a significant influence on their responses. The difficulty in forming consistent decisions about unfamiliar ecosystem services has limited the applicability of the conventional CV approach (Carson et al. 2001, Barkmann et al. 2008). Some authors have argued for the need to let ESBs identify ecosystem services and functional diversity components linked to them in their own terms (e.g., De Chazal et al. 2008, Quétier et al. 2010, Díaz et al. 2011). However, to our knowledge, this approach has yet to be combined with economic valuation techniques. Until that happens, it is difficult to assess whether the pre-definition of ESP and ecosystem services by researchers has a significant impact on ESB responses in CV studies.

Third, the fact that the methods applied in this article failed to increase the visibility of biodiversity or ecosystem properties in the economic valuation of ecosystem services may be the result of inherent limitations of the economic valuation techniques themselves. As described in the Methods section, mainstream economic valuation has a number of problems when applied to natural resources, related to: some of its underlying economic assumptions (Dequech 2007), its 
TABLE 6. Heckman model results showing the determinant factors for being willing to pay for ecosystem services.

\begin{tabular}{|c|c|c|}
\hline Variables & Probit coefficient & 2SLS coefficient \\
\hline Constant & $2.034 \dagger(1.111)$ & $4.244 *(1.761)$ \\
\hline Years familiar & $-0.007 *(0.004)$ & \\
\hline Distance & & $0.078+(0.040)$ \\
\hline $\mathrm{N}^{\circ}$ ecosystem services & $0.140 *(0.069)$ & $0.165 \dagger(0.096)$ \\
\hline Provisioning ecosystem services & $-0.298+(0.194)$ & \\
\hline Water quality & $0.304 *(0.141)$ & $0.443 \dagger(0.231)$ \\
\hline Air quality & $0.201(0.134)$ & \\
\hline Climate regulation & $0.202(0.137)$ & \\
\hline Soil quality & $0.290 *(0.143)$ & \\
\hline Individual satisfaction for conserving biodiversity & $0.493 *(0.155)$ & $0.541 *(0.254)$ \\
\hline NGO & $0.332 \dagger(0.194)$ & $0.552 \dagger(0.305)$ \\
\hline Recycling & $0.082(0.073)$ & $0.178(0.120)$ \\
\hline Education & $-0.115(0.092)$ & \\
\hline Age & $-0.781 *(0.241)$ & $-1.190 * *(0.331)$ \\
\hline Income & $0.031(0.139)$ & $0.038(0.210)$ \\
\hline House size & $0.007(0.535)$ & $0.035(0.086)$ \\
\hline$\Lambda$ & & $2.306 * *(0.077)$ \\
\hline Log likelihood & -247.54 & -542.83 \\
\hline Chi-square & $57.20^{* * *} *$ & \\
\hline Pseudo- $R^{2}$ & 0.21 & \\
\hline Correct predictions & $66 \%$ & \\
\hline Adjusted $R^{2}$ & & 0.80 \\
\hline
\end{tabular}

Notes: Probit regression results are for the first stage of the Heckman model and sample selection two-stage least-squares regression (2SLS) results are for second stage of the Heckman model (with standard errors in parentheses). The dependent variable in PROBIT regression is 0 when willingness to pay $(\mathrm{WTP})=0$ and 1 when WTP $>0$. The dependent variable in 2SLS is $\ln (\mathrm{WTP})$. Empty cells reflect the fact that not all variables were used in both analyses. $\dagger P<0.10 ; * P<0.05$; ** $P<0.01$; *** $P<0.001$.

dependence on the ability to pay (García-Llorente et al. 2011), its unfamiliarity (i.e., information and methodological misspecification bias; Barkmann et al. 2008), its inability to reflect those components of biodiversity, ecosystem properties and ecosystem services that are not amenable to monetary valuation (Spangenberg and Settele 2010), and the interests of stakeholders who are not closely involved with mainstream markets (Trainor 2006). Other critics emphasize the fact that CV exercises are unreliable because they can only deal with consumer preferences (based on conceptions of the good lives that individuals seek for themselves) but not with citizen preferences (based on conceptions of the good society provided by the consideration and agreement of others). A way to strengthen $\mathrm{CV}$ exercises against the latter limitation, but not necessarily against the other limitations mentioned above, is to apply deliberative methods.
In these methods, individuals participate in a discursive process in which they construct collective judgments as citizens about the value of a public environmental good (Sagoff 1998, Spash 2007, Hermans et al. 2008). In addition, new environmental economics techniques, such as choice experiments, in which any ecosystem service can be described in terms of its characteristics, could help respondents to make more informed decisions and avoid the misspecification bias that has traditionally distorted the valuation results in $\mathrm{CV}$ methods (Bateman et al. 2002, Barkmann et al. 2008, Schläpfer 2008).

The fourth explanation is related to the ability of the economic valuation approach to visualize the importance of biodiversity for human well-being through reframing ecosystem properties as services values (Sagoff 2011). When we translate an ecosystem function by

TABLE 7. Mean scores for WTP for total ecosystem services and per ecosystem service in each category (provisioning, regulating, and cultural) (SE in parentheses) and ANOVA results for the effect of ecosystem services categories.

\begin{tabular}{lrccrr}
\hline \hline & & & \multicolumn{2}{c}{ Ecosystem service mean WTP $(€ /$ year $)$} \\
\cline { 4 - 6 } Ecosystem service beneficiaries & $N$ & Total WTP $(€ /$ yr $)$ & Provisioning & Regulating & Cultural \\
\hline Locals with high dependence & 24 & $12.08(6.94)$ & $3.08(1.05)$ & $3.50(1.12)$ & $3.02(1.06)$ \\
Locals with low dependence & 79 & $12.63(6.35)$ & $3.10(0.81)$ & $3.38(0.79)$ & $3.04(0.82)$ \\
Environmental professionals & 81 & $53.16(5.67)$ & $3.12(0.64)$ & $3.78(1.53)$ & $2.98(0.61)$ \\
Other professionals & 110 & $30.85(5.87)$ & $3.13(0.79)$ & $3.62(0.72)$ & $2.99(0.73)$ \\
General tourist & 17 & $20.74(5.53)$ & $2.88(0.44)$ & $3.50(0.52)$ & $3.02(0.50)$ \\
Nature tourist & 93 & $18.82(6.71)$ & $2.91(0.74)$ & $3.25(0.71)$ & $2.99(1.24)$ \\
Total sampling & 404 & $23.98(6.55)$ & $3.06(0.76)$ & $3.51(0.99)$ & $3.00(0.88)$ \\
\hline
\end{tabular}

Note: For total sampling, $F=30.98, P<0.001$. 


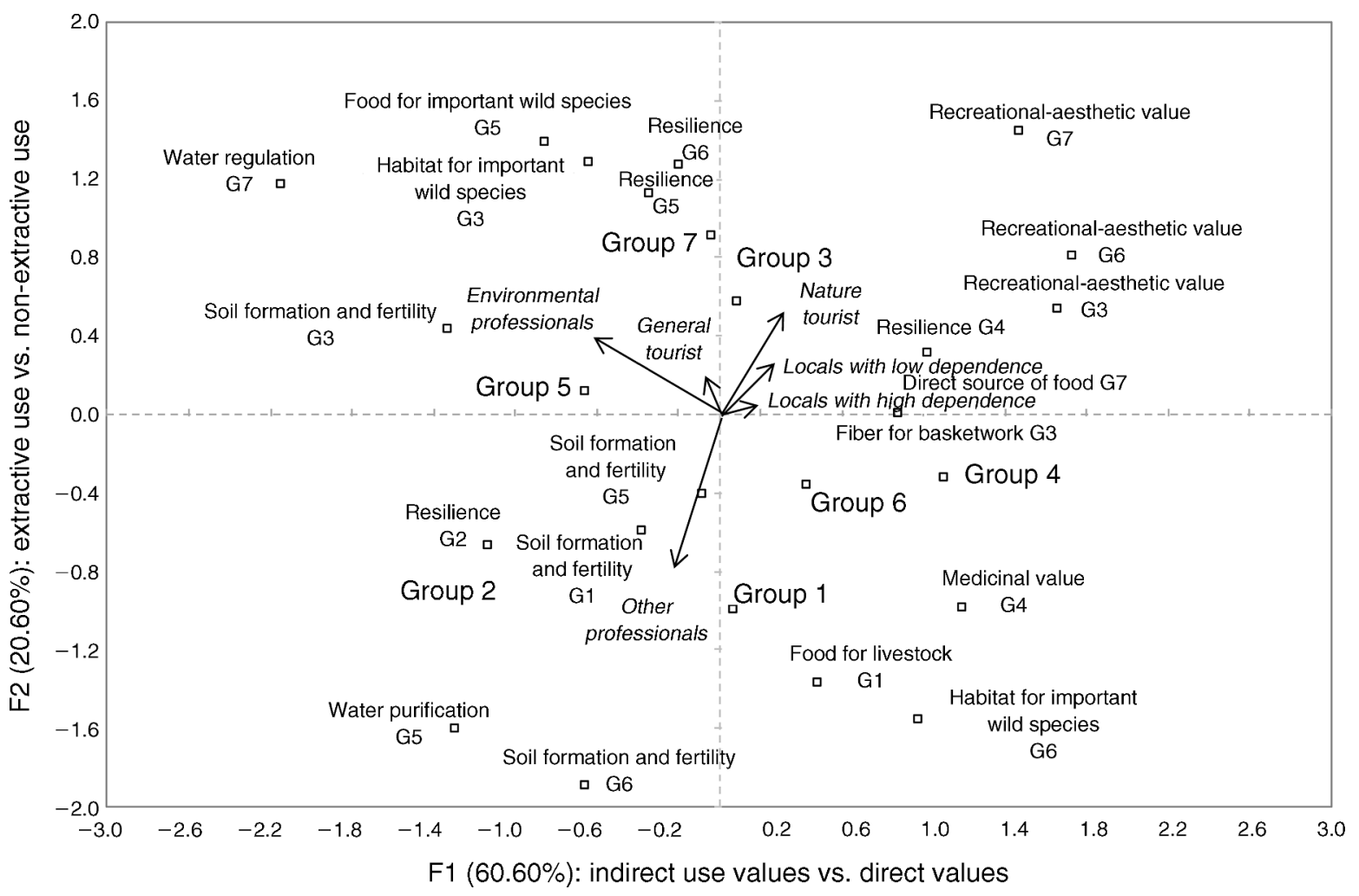

FIG. 5. Canonical correspondence analysis (CCA) ordination diagram depicting the relationship between ecosystem service beneficiaries (ESBs; lightface italic type) and their willingness to pay (WTP) for ecosystem service providers (ESPs) and ecosystem services (open squares). Key to abbreviations for aquatic plant functional groups generating each particular ecosystem service: G1, group 1; G2, group 2; G3, group 3; G4, group 4; G5, group 5; G6, group 6; G7, group 7.

reframing it as an economic value of services, there is a risk of hiding the contribution of the ESPs involved in the provision of these services (Peterson et al. 2009). This situation may result in problems when applying the economic valuation frameworks of ecosystem services based on the best ecological information (Luck et al. 2009, Kontogianni et al. 2010) together with more pragmatic and economic approaches (Boyd and Banzhaf 2007, TEEB 2009). In fact, our findings do suggest that simply incorporating ESP and ecosystem processes into the CV exercise is not enough to overcome the lack of visibility of nature in the economic valuation of ecosystem services. At this point, far from making people fit the neoclassical economic model, perhaps researchers should focus on rethinking the model to conform more closely to society, questioning the underlying assumption that ecosystem functions can be made fully visible by defining them through the economic value of their derived services. The ecosystem service valuation framework can be informative, but the dominance of its economic dimension may be distracting (Norgaard 2010).

All four of these aspects - the uniqueness of the Doñana situation, the a priori definition of ecosystem services and ESP categories by researchers, the inherent bias of the $\mathrm{CV}$ technique, and the intrinsic limitations of the economic valuation framework to adequately reflect nature's value to people - might have influenced the outcome of our case study, and only further work will allow us to find out in which proportions.

There is abundant evidence that the concept of ecosystem services is making societies, from individuals to national governments and international conventions, more aware of and willing to protect biodiversity and ecosystems. However, it has been increasingly argued that techniques based on neoclassical economics and markets and on a single metric (often money) fail to consider the many realms of value that people place on ecosystems (Trainor 2006, Norgaard 2010). Because of that, some authors advocate for the valuation of the benefits provided by nature with criteria other than, or in addition to, economic methods (Trainor 2006, Spangenberg and Settele 2010, Díaz et al. 2011). For example, in study cases like ours, the importance of biodiversity for human well-being could be assessed through the analysis of the connections of specific components of functional diversity with the specific interest and priorities of different ESBs who are asked to rank their priorities by importance to their quality of life, without the need to express this value in monetary terms (Díaz et al. 2011). 


\section{ACKNOWLEDGMENTS}

We thank the Doñana National and Natural Park staff, Department of Environment of Andalusian Government staff, and Fundación Doñana for providing the facilities used to obtain our data, especially I. Palomo for the cartographic work. We thank I. Palomo, I. Iniesta, E. Oteros, and D. García for their assistance during sampling. We greatly appreciate the valuable comments made by P. Harrison on an earlier version of the manuscript, and two anonymous reviewers for constructive suggestions. This research was partially supported by a grant from the Madrid Regional Government of Education, which was co-funded by the Social European Fund (F.S.E.), the Spanish Ministry of Education and Science (Project CGL200614121/BOS), and the Spanish Ministry of the Environment and Rural and Marine Affairs through project 018/2009. S. Díaz acknowledges support from FONCyT and CONICET (Argentina) and IAI (CRN 2015, supported by US NSF GEO0452325).

\section{Literature Cited}

Aldred, J. 2006. Incommensurability and monetary valuation. Land Economics 82:141-161.

Allen, L. H. 1997. Mechanisms and rates of O-2 transfer to and through submerged rhizomes and roots via aerenchyma. Soil and Crop Science Society of Florida Proceedings 56:41-54.

Anton, C., et al. 2010. Research needs for incorporating the ecosystem service approach into EU biodiversity conservation policy. Biodiversity and Conservation 19:2979-2994.

Barkmann, J., K. Glenk, A. Keil, C. Leemhuis, N. Dietrich, G. Gerold, and R. Marggraf. 2008. Confronting unfamiliarity with ecosystem functions: the case for an ecosystem service approach to environmental valuation with stated preference methods. Ecological Economics 65:48-62.

Bateman, I. J., et al. 2002. Economic valuation with stated preference techniques: a manual. Edward Elgar, Northampton, Massachusetts, USA.

Bekker, R., J. Bakker, U. Grandin, R. Kalamees, P. Milberg, P. Poschlod, K. Thompson, and J. Willems. 1998. Seed size, shape and vertical distribution in the soil: Indicators of seed longevity. Functional Ecology 12:834-842.

Blondel, J. 2006. The "design" of Mediterranean landscapes: a millennial story of humans and ecological systems during the historic period. Human Ecology 34:713-729.

Boyd, J., and S. Banzhaf. 2007. What are ecosystem services? The need for standardized environmental accounting units. Ecological Economics 63:616-626.

Carpenter, S. R., and D. M. Lodge. 1986. Effects of submersed macrophytes on ecosystem processes. Aquatic Botany 26:341-370.

Carpenter, S. R., et al. 2009. Science for managing ecosystem services: Beyond the Millennium Ecosystem Assessment. Proceedings of the National Academy of Sciences USA 106:1305-1312.

Carson, R. T., N. E. Flores, and N. F. Meade. 2001. Contingent valuation: controversies and evidence. Environmental and Resource Economics 19:173-210.

Chapin, F. S. III, M. S. Bret-Harte, S. E. Hobbie, and H. Zhong. 1996. Plant functional types as predictors of transient responses of arctic vegetation to global change. Journal of Vegetation Science 7:347-358.

Chapin, F. S., III., E. S. Zavaleta, V. T. Eviner, R. L. Naylor, P. M. Vitousek, H. L. Reynolds, D. U. Hooper, S. Lavorel, O. E. Sala, S. E. Hobbie, M. C. Mack, and S. Díaz. 2000. Consequences of changing biodiversity. Nature 405:234-242.

Charalambidou, I. C., L. Santamaria, and O. Langevoord. 2003. Effect of ingestion by five duck dispersers on the retention time, retrieval and germination of Ruppia maritima seeds. Functional Ecology 17:747-753.

Chiarello, N. R. 1989. Phenology of California grasslands. Pages 47-58 in L. F. Huenneke and H. Mooney, editors.
Grassland structure and function. California annual grassland. Kluwer Academic Publishers, Dordrecht, The Netherlands.

Coley, P. D. 1980. Effects of leaf age and plant life history patterns on herbivory. Nature 284:545-546.

Coops, H., F. C. M. Kerkum, M. S. van den Berg, and I. van Splunder. 2007. Submerged macrophyte vegetation and the European Water Framework Directive: assessment of status and trends in shallow alkaline lakes in the Netherlands. Hydrobiologia 584:395-402.

Cornelissen, J. H. C., S. Lavorel, E. Garnier, S. Díaz, N. Buchmann, D. E. Gurvich, P. B. Reich, H. Ter Steege, H. D. Morgan, M. G. A. Van Der Heijden, J. G. Pausas, and H. Poorter. 2003. A handbook of protocols for standardized and easy measurement of plant functional traits worldwide. Australian Journal of Botany 51:335-380.

Cornelissen, J. H. C., N. Pérez-Harguindeguy, S. Díaz, J. P. Grime, B. Marzano, M. Cabido, F. Vendramini, and B. Cerabolini. 1999. Leaf structure and defence control litter decomposition rate across species, life forms and continents. New Phytologist 43:191-200.

Council of the European Communities. 2000. Directive of the European Parliament and of the Council Establishing a Framework for Community Action in the Field of Water Policy (2000/60/EC). Official Journal of the European Communities 43:1-73.

Dawson, F. H., and W. N. Robinson. 1984. Submerged macrophytes and the hydraulic resistance of a lowland chalkstream. Verhandlungen des Internationalen Verein Limnologie 22:1944-1948.

De Bello, F., et al. 2010. Towards an assessment of multiple ecosystem processes and services via functional traits. Biodiversity and Conservation 19:2873-2893.

De Chazal, J., F. Quétier, S. Lavorel, and A. Van Doorn. 2008. Including multiple differing stakeholder values into vulnerability assessments of socio-ecological systems. Global Environmental Change 18:508-510.

Dequech, D. 2007. Neoclassical, mainstream, orthodox, and heterodox economics. Journal of Post Keynesian Economics 30:279-302.

Díaz, S., A. Acosta, and M. Cabido. 1992. Morphological analysis of herbaceous communities under different grazing regimes. Journal of Vegetation Science 3:689-696.

Díaz, S., and M. Cabido. 2001. Vive la difference: plant functional diversity matters to ecosystem processes. Trends in Ecology and Evolution 16:646-655.

Díaz, S., J. Fargione, F. S. III. Chapin, and D. Tilman. 2006. Biodiversity loss threatens human well-being. PloS Biology 4:1300-1305.

Díaz, S., et al. 2004. The plant traits that drive ecosystems: Evidence from three continents. Journal of Vegetation Science 15:295-304

Díaz, S., S. Lavorel, F. De Bello, F. Quétier, K. Grigulis, and T. M. Robison. 2007. Incorporating plant functional diversity effects in ecosystem service assessments. Proceedings of the National Academy of Science 104:20684-20689.

Díaz, S., F. Quértier, D. M. Cáceres, S. F. Trainor, N. PérezHarguindeguy, M. Syndonia Bret-Harte, B. Finegan, M. Peña-Claros, and L. Poorter. 2011. Linking functional diversity and social actor strategies in a framework for interdisciplinary analysis of nature's benefits to society. Proceedings of the National Academy of Science 3:895-902.

Duarte, C., C. Montes, S. Agustí, P. Martino, M. Bernués, and J. Kalff. 1990. Biomasa de macrófitos acuáticos en la Marisma del Parque Nacional de Doñana (SW de España): importancia y factores ambientales que controlan su distribución. Limnetica 6:1-12.

Egoh, B., M. Rouget, B. Reyers, A. T. Knight, R. M. Cowling, A. S. van Jaarsveld, and A. Welz. 2007. Integrating ecosystem services into conservation assessments: a review. Ecological Economics 63:714-721. 
Elbersen, B. 2001. Nature on the doorstep. The relationship between protected natural areas and residential activity in the European countryside. Alterra, Utrecht/Wageningen, Netherlands.

Engelhardt, K. A. M. 2006. Relating effect and response traits in submersed aquatic macrophytes. Ecological Applications 16:1808-1820.

Engelhardt, K. A. M., and M. Ritchie. 2002. The effect of aquatic plant species richness on wetland ecosystem processes. Ecology 83:2911-2924.

Espinar, J. L., L. V. García, P. García-Murillo, and J. Toja. 2002. Submerged macrophyte zonation in a Mediterranean salt marsh: a facilitation effect from established helophytes? Journal of Vegetation Science 13:831-840.

Farmer, A. M., and D. H. N. Spence. 1986. The growth strategies and distribution of isoetids in Scottish freshwater lochs. Aquatic Botany 26:247-258.

Ferreira, M. T., and F. C. Aguiar. 2006. Riparian and aquatic vegetation in Mediterranean-type streams (western Iberia). Limnetica 25:411-424.

Figuerola, J., and A. J. Green. 2002. The role of waterfowl in the passive transport of aquatic organism: from local processes to long-distance. Ph.D. Dissertation, Universidad Autónoma de Madrid, Madrid, Spain.

Figuerola, J., A. J. Green, and L. Santamaría. 2002. Comparative dispersal effectiveness of wigeongrass seeds by waterfowl wintering in south-west Spain: quantitative and qualitative aspects. Journal of Ecology 90:989-1001.

Figuerola, J., L. Santamaría, A. J. Green, I. Luque, R. Alvarez, and I. Charalambidou. 2005. Endozoochorous dispersal of aquatic plants: does seed gut passage affect plant performance? American Journal of Botany 92:696-699.

Folke, C. 2006. The economic perspective: conservation against development versus conservation for development. Conservation Biology 20:686-688.

Folke, C., J. Colding, and F. Berkes. 2003. Synthesis: building resilience and adaptive capacity in social-ecological systems. Pages 352-387 in F. Berkes, J. Colding, and C. Folke, editors. Navigating social-ecological systems: building resilience for complexity and change. Cambridge University Press, Cambridge, UK.

García-Llorente, M., B. Martín-López, J. A. González, P. Alcorlo, and C. Montes. 2008. Social perceptions of the impacts and benefits of invasive alien species: implications for management. Biological Conservation 141:2969-2983.

García-Llorente, M., B. Martín-López, and C. Montes. 2011. Exploring the motivations of protesters in contingent valuation: Insights for conservation policies. Environmental Science and Policy 14:76-88.

García-Murillo, P., R. C. S. Fernández-Zamudio, and A. Sousa. 2006. Aquatic macrophytes in Doñana protected area (SW Spain): an overview. Limnetica 25:71-80.

García-Novo, F., and C. Marín-Cabrera. 2006. Doñana. Water and biosphere. Confederación Hidrográfica del Guadalquivir. Ministerio de Medio Ambiente, Madrid, Spain.

Garrido, H. 2000. Palabrero de Doñana. Introducción al léxico tradicional de las Marismas del Guadalquivir. Editorial Rueda, Madrid, Spain.

Gómez-Baggethun, E., S. Mingorria, V. Reyes-García, L. Calvet, and C. Montes. 2010. Traditional ecological knowledge trends in the transition to a market economy: empirical study in the Doñana Natural Areas. Conservation Biology 24:721-729.

Grace, J. B. 1993. The adaptive significance of clonal reproduction in angiosperms: an aquatic perspective. Aquatic Botany 44:159-180.

Grigulis, K., S. Lavorel, I. D. Davies, A. Dossantos, F. Lloret, and M. Vilà. 2005. Landscape-scale positive feedbacks between fire and expansion of the large tussock grass, Ampelodesmos mauritanica, in Catalan shrublands. Global Change Biology 11:1042-1053.
Grime, J. P., J. H. C. Cornelissen, K. Thompson, and J. G. Hodgson. 1996. Evidence of a causal connection between antiherbivore defence and the decomposition rate of leaves. Oikos 77:489-494.

Gusewell, S. 2005. Nutrient resorption of wetland graminoids is related to the type of nutrient limitation. Functional Ecology 19:344-354.

Harrington, R., et al. 2010. Ecosystem services and biodiversity conservation: concepts and a glossary. Biodiversity Conservation 19:2773-2790.

Harrison, P. A., et al. 2010. Identifying and prioritizing services in European terrestrial and freshwater ecosystems. Biodiversity and Conservation 19:2791-2821.

Heckman, J. J. 1979. Sample selection bias as a specification error. Econometrica 1:153-161.

Hermans, C., R. B. Howarth, T. Noordewier, and J. Erickson. 2008. Constructing preferences in structured group deliberative processes. Pages 50-79 in C. Zografos and R. B. Howarth, editors. Deliberative ecological economics. Oxford University Press, New Delhi, India.

Holling, C. S. 1973. Resilience and stability of ecological systems. Annual Review of Ecology and Systematics 4:1-23.

Hooper, D. U., et al. 2005. Effects of biodiversity on ecosystem functioning: a consensus of current knowledge. Ecological Monographs 75:3-35.

Hrivnák, R., H. Ot'ahel'ová, and I. Jarolímek. 2006. Diversity of aquatic macrophytes in relation to environmental factors in the Slatina river (Slovakia). Biologia 61:413-419.

Idestam-Almquist, J. 1998. Waterfowl herbivory on Potamogeton pectinatus in the Baltic Sea. Oikos 81:323-328.

Jansson, R., U. Zinko, D. M. Merritt, and C. Nilsson. 2005. Hydrochory increases riparian plant species richness: a comparison between a free-flowing and a regulated river. Functional Ecology 93:1094-1103.

Jaynes, M. L., and S. R. Carpenter. 1986. Effects of vascular and nonvascular macrophytes on sediment redox and solute dynamics. Ecology 67:875-882.

Jongman, R. H. G., C. J. F. ter Brank, and O. F. R. van Tongeren. 1987. Data analysis in community and landscape ecology. Pudoc, Wageningen, The Netherlands.

Jorgensen, B. S., M. A. Wilson, and T. A. Haberlein. 2001. Fairness in the contingent valuation of environmental public goods: attitude towards paying for environmental improvement at two levels of scope. Ecological Economics 36:133148.

Kahneman, D., and I. Ritov. 1999. Economic preferences or attitude expressions? An analysis of dollar responses to public issues. Journal of Risk and Uncertainty 19:203-235.

Kendal, D., K. Williams, and L. Armstrong. 2008. Preference for and performance of some Australian native plants grown as hedges. Urban Forestry and Urban Greening 7:93-106.

Kleyer, M., et al. 2008. The LEDA traitbase: a database of lifehistory traits of Northwest European flora. Journal of Ecology 96:1266-1274.

Kontogianni, A., G. W. Luck, and M. Skourtos. 2010. Valuing ecosystem services on the basis of service-providing units: a potential approach to address the "endpoint problem" and improve stated preference methods. Ecological Economics 69:1479-1487.

Lacoul, P., and B. Freedman. 2006. Environmental influences on aquatic plants in freshwater ecosystems. Environmental Reviews 14:89-136.

Lee, L. F., and G. S. Maddala. 1985. The common structure of tests for selective bias, serial correlation, heterodasticity and nonnormality in the Tobit model. International Economic Review 26:1-10.

Leishman, M. R., and M. Westoby. 1994. The role of size in seedling establishment in dry soil conditions-experimental evidence from semi-arid species. Journal of Ecology 82:249258. 
Levine, J. M. 2000. Complex interactions in a streamside plant community. Ecology 81:3431-3444.

Lloret, F., and M. Vilà. 2009. Diversity patterns of plant functional types in relation to fire regime and previous land use in Mediterranean woodlands. Journal of Vegetation Science 14:387-398.

Luck, G. W., et al. 2009. Quantifying the contribution of organisms to the provision of ecosystem services. BioScience 59:223-235.

Macek, P. 2008. The role of clonal plants in wetlands. Dissertation. University of South Bohemia, České Budějovice, Czech Republic.

Margalef, R. 1983. Limnologia. Ediciones Omega, Barcelona, Spain.

Martín-López, B., M. García-Llorente, I. Palomo, and C. Montes. 2011. The conservation against development paradigm in protected areas: valuation of ecosystem services in the Doñana social-ecological system (southwestern Spain). Ecological Economics 70:1481-1491.

Martín-López, B., C. Montes, and J. Benayas. 2007. Influence of user characteristics on valuation of ecosystem services in Doñana natural protected area (south-west Spain). Environmental Conservation 34:215-224.

McMichael, T., B. Scholes, M. Hefny, E. Pereira, C. Palm, and S. Foale. 2005. Linking ecosystem services and human wellbeing in subglobal assessments. Pages 43-60 in D. Capistrano and C. Samper, editors. Sub-global assessments of the Millennium Ecosystem Assessment. Island Press, Washington, D.C., USA.

Meilinger, P., S. Schneider, and A. Melzer. 2005. The reference index method for the macrophyte-based assessment of rivers: a contribution to the implementation of the European Framework Directive in Germany. International Review of Hydrobiology 90:322-342.

Menzel, S., and J. Teng. 2010. Ecosystem services as a stakeholder-driven concept for conservation science. Conservation Biology 24:907-909.

Mitchell, R. C., and R. T. Carson. 1989. Using survey to value public goods. The contingent valuation method. Resources for the Future, Washington, D.C., USA.

Mitsch, W. J., J. K. Cronk, X. Wu, R. W. Nairn, and D. L. Hey. 1995. Phosphorus retention in constructed freshwater riparian marshes. Ecological Applications 5:830-845.

Montes, C., F. Borja, M. A. Bravo, and J. M. Moreira. 1998. Reconocimiento biofísico de espacios naturales protegidos. Doñana: Una aproximación ecosistémica. El mapa ecológico de Doñana. Consejería de Medio Ambiente, Junta de Andalucía, Spain.

Montgomery, C. 2002. Ranking the benefits of biodiversity: an exploration of relative values. Journal of Environmental Management 65:313-326.

Nolet, B. A., O. Langevoord, R. M. Bevan, K. R. Engelaar, M. Klaasem, R. J. W. Mulder, and S. Van Dijk. 2001. Spatial variation in tuber depletion by swans explained by differences in net intake rates. Ecology 82:1655-1667.

Norgaard, R. B. 2010. Ecosystem services: from eye-opening metaphor to complexity blinder. Ecological Economics 69:1219-1227.

Ojeda, J. F. 1992. Políticas forestales y medio ambiente en Doñana y su entorno. Agricultura y Sociedad 65:303-357.

Ostrom, E. 2009. A general framework for analyzing sustainability of social-ecological systems. Science 325:419-422.

Paracuellos, M. 2006. Relationships of songbird occupation with habitat configuration and bird abundance in patchy reed beds. Ardea 94:87-98.

Paracuellos, M., and J. L. Telleria. 2004. Factors affecting the distribution of a waterbird community: the role of habitat configuration and bird abundance. Waterbirds 27:446-453.

Pascual, U., R. Muradian, L. Brander, E. Gómez-Baggethun, B. Martín-López, M. Verman, P. Armsworth, M. Christie, H. Cornelissen, F. Eppink, and others. 2010. The economics of valuing ecosystem services and biodiversity. Pages 183-255 in P. Kumar, editor. The economics of ecosystems and biodiversity: ecological and economic foundations. Earthscan, London, UK.

Pearce, D. 2000. Cost-benefit analysis and environmental policy. Pages 48-74 in D. Helm, editor. Environmental policy. Oxford University Press, Oxford, UK.

Pearce, D., and R. K. Turner. 1990. Economics of natural resources ant the environment. BPCC Wheatsons Ltd., Exeter, UK.

Peco, B., J. Traba, C. Levassor, A. M. Sánchez, and F. M. Azcárate. 2003. Seed size, shape and persistence in dry Mediterranean grass and scrublands. Seed Science Research 13:87-95.

Peterson, M. J., D. M. Hall, A. M. Feldpausch-Parker, and T. Rai Peterson. 2009. Obscuring ecosystem function with application of the ecosystem services concept. Conservation Biology 24:113-119.

Pollux, B. J. A., L. Santamaria, and N. J. Ouborg. 2005. Differences in endozoochorous dispersal between aquatic plant species, with reference to plant population persistence in rivers. Freshwater Biology 50:232-242.

Quétier, F., F. Rivoal, P. Marty, J. De Chazal, W. Thuiller, and S. Lavorel. 2010. Social representations of the alpine grassland landscape and socio-political discourses on rural development. Regional Environmental Change 10:119:130.

Read, J., and A. Stokes. 2006. Plant biomechanics in an ecological context. American Journal of Botany 93:15461565.

Rivera-Nuñez, D., and C. Obón de Castro. 1991. La guía de INCAFO de las plantas útiles y venenosas de la Península Ibérica y Baleares; excluidas medicinales. INCAFO, S.A., Madrid, Spain.

Sagoff, M. 1998. Aggration and deliberation in valuing environmental public goods: a look beyond contingent pricing. Ecological Economics 24:213-230.

Sagoff, M. 2011. The quantification and valuation of ecosystem services. Ecological Economics 70:497-502.

Schläpfer, F. 2008. Contingent valuation: a new perspective. Ecological Economics 64:729-740.

Serrano, L., M. Reina, G. Martín, I. Reyes, A. Arechederra, D. Léon, and J. Toja. 2006. The aquatic systems of Doñana (SW Spain): watersheds and frontiers. Limnetica 25:11-32.

Sigelman, L., and L. Zeng. 1999. Analyzing censored and sample selected data with Tobit and Heckit models. Political Analysis 8:167-182.

Sodhi, N. S., T. M. Lee, C. H. Sekercioglu, E. L. Webb, D. M. Prawiradilaga, D. J. Lohman, N. E. Pierce, A. C. Diesmos, M. Rao, and P. R. Ehrlich. 2010. Local people value environmental services provided by forested parks. Biodiversity and Conservation 19:1175-1188.

Spangenberg, J. H., and J. Settele. 2010. Precisely incorrect? Monetising the value of ecosystem services. Ecological Complexity 7:327-337.

Spash, C. L. 2007. Deliberative monetary valuation (DMV): Issues in combining economic and political processes to value environmental change. Ecological Economics 63:690-699.

Stelzer, D., S. Schneider, and A. Melzer. 2005. Macrophytebased assessment of lakes. a contribution to the implementation of the European Water Framework Directive in Germany. International Review of Hydrobiology 90:223237.

Sukhdev, P. 2011. Putting a price on nature: the economics of ecosystems and biodiversity. Solutions 1:34-43.

TEEB (The Economics of Ecosystems and Biodiversity). 2009. The economics of ecosystems and biodiversity for national and international policy makers. Summary: responding to the value of nature. Welzel + Hardt, Wesseling, Germany.

Thompson, K., S. R. Band, and J. G. Hodson. 1993. Seed size and seed shape predict persistence in soil. Functional Ecology 7:236-241. 
Thomson, W. 1994. Guía práctica ilustrada de las plantas medicinales. Blume, Barcelona, Spain.

Trainor, S. F. 2006. Realms of value: conflicting natural resource values and incommensurabiliy. Environmental Values 15:3-29.

Turner, B. L., II, et al. 2003. A framework for vulnerability analysis in sustainability science. Proceedings of the National Academy of Sciences USA 100:8074-8079.

Turner, R. K., S. Morse-Jones, and B. Fisher. 2010. Ecosystem valuation. a sequential decision support system and quality assessment issues. Annals of the New York Academy of Sciences 1185:79-101.

Underwood, E. C., K. R. Klausmeyer, R. L. Cox, S. M. Busby, S. A. Morrison, and M. R. Shaw. 2008. Expanding the global network of protected areas to save the imperiled Mediterranean biome. Conservation Biology 23:43-52.

Valdés, B., S. Talavera, and E. Fernández Galiano. 1987. Flora vascular de Andalucía Occidental (I, II, III). Ketres, Barcelona, Spain.
Vatn, A., and D. W. Bromley. 1994. Choices without prices without apologies. Journal of Environmental Economics and Management 26:129-148.

Voigts, D. K. 1976. Aquatic invertebrate abundance in relation to changing marsh vegetation. American Midland Naturalist 95:313-322.

Ward, J. 1963. Hierarchical grouping to optimize and objective function. Journal of the American Statistical Association 58:236-244.

Willby, N. J., V. J. Abernethy, and B. O. L. Demars. 2000. Attribute-based classification of European hydrophytes and its relationship to habitat utilization. Freshwater Biology 43:43-74

Wilson, M. A., and S. R. Carpenter. 1999. Economic valuation of freshwater ecosystem services in the United States: 19711997. Ecological Applications 9:772-783.

Wu, X., and W. J. Mitsch. 1998. Spatial and temporal patterns of algae in newly constructed freshwater wetlands. Wetlands 18:9-20.

\section{APPENDIX A}

List of aquatic plant species in Doñana (SW Spain) considered in the study (Ecological Archives A021-138-A1).

\section{APPENDIX B}

Questionnaire (Ecological Archives A021-138-A2).

\section{APPENDIX C}

Functional groups obtained through the nonhierarchical cluster classification of aquatic plants based on trait attributes (Ecological Archives A021-138-A3).

\section{APPENDIX D}

Factor loadings derived from principal component analysis (PCA) to characterize ecosystem service providers (ESPs) (Ecological Archives A021-138-A4).

\section{APPENDIX E}

Factor loadings derived from principal component analysis (PCA) to characterize ecosystem service beneficiaries (ESBs) (Ecological Archives A021-138-A5).

\section{APPENDIX F}

Factor loadings derived from canonical correspondence analysis (CCA) for relationships between ecosystem service beneficiaries (ESBs) and their willingness to pay (WTP) for the ecosystem service delivery by ecosystem service providers (ESPs) and the ESPs themselves (Ecological Archives A021-138-A6). 